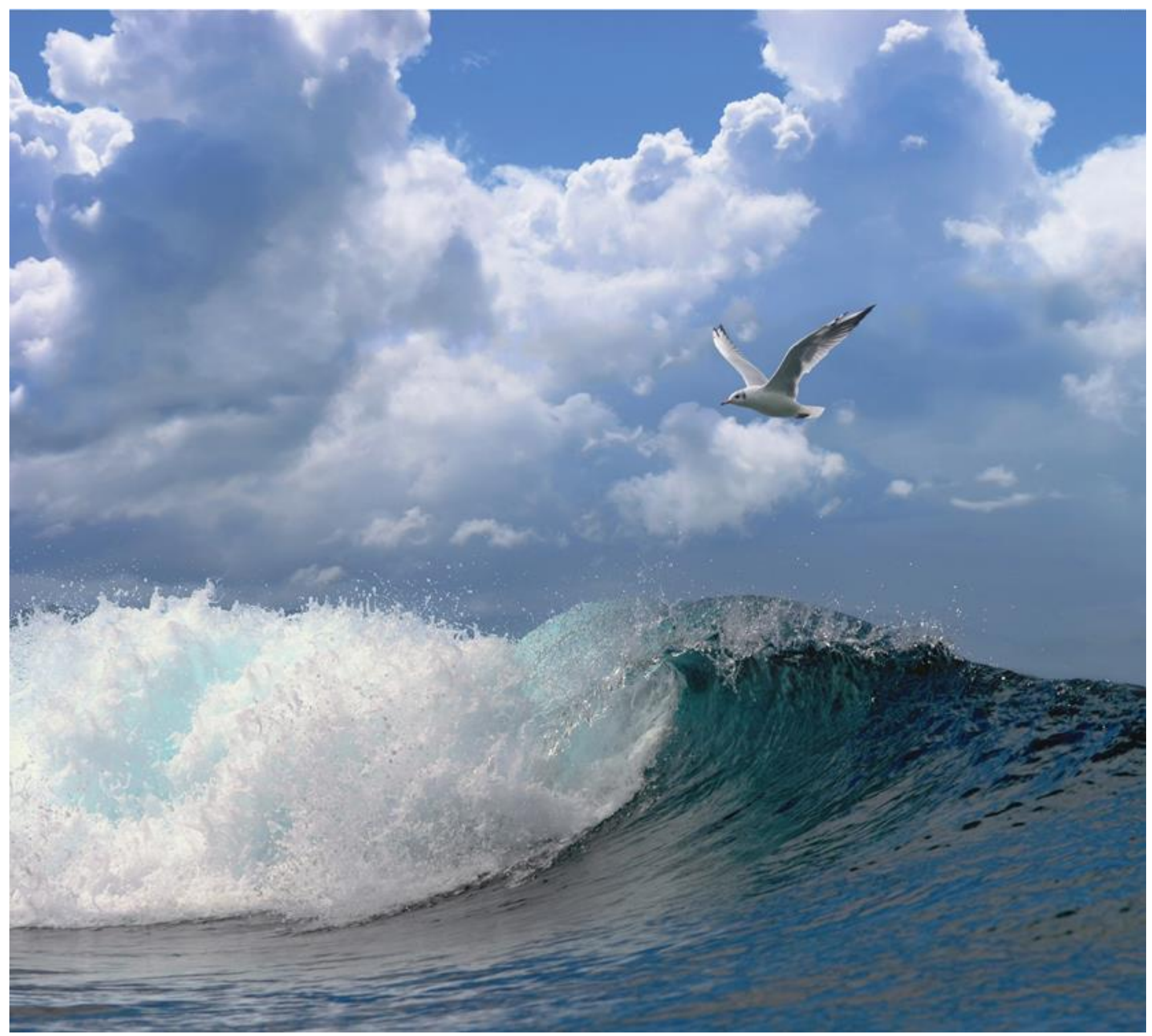

\title{
Co-cultivation of the seaweed Ulva sp. and Mytilus edulis
}




\section{Co-cultivation of the seaweed U/va sp. and Mytilus edulis}

Author(s): $\quad$ Tonk L \& HM Jansen

Publication date: Februari 2019

This research project was carried out by Wageningen Marine Research at the request of and with funding from the North Sea Farm (NSF) and the Ministry of Economic Affairs for the purposes of Policy Support Research Theme 'Maatschappelijk Innovatieprogramma PROSEAWEED' (project number BO-47-001-001)

Wageningen Marine Research

Yerseke, Februari 2019

CONFIDENTIAL no

Wageningen Marine Research report C011/19 
Keywords: Seaweed, shellfish, production.

Client: $\quad$ Stichting Noordzeeboerderij

Zeestraat 84

2518 AD, Den Haag

This report can be downloaded for free from https://doi.org/10.18174/470705

Wageningen Marine Research provides no printed copies of reports

Wageningen Marine Research is ISO 9001:2015 certified.

(C) Wageningen Marine Research

Wageningen Marine Research institute of Stichting Wageningen Research is registered in the Dutch traderecord nr. 09098104, BTW nr. NL 806511618
The Management of Wageningen Marine Research is not responsible for resulting damage, as well as for damage resulting from the application of results or research obtained by Wageningen Marine Research, its clients or any claims related to the application of information found within its research. This report has been made on the request of the client and is wholly the client's property. This report may not be reproduced and/or published partially or in its entirety without the express written consent of the client. 


\section{Contents}

$\begin{array}{lr}\text { Summary } & 4\end{array}$

$\begin{array}{llr}1 & \text { Introduction } & 5\end{array}$

1.1 Background $\quad 5$

1.2 Ulva nutrient dynamics and productivity 25

$\begin{array}{llc}1.3 & \text { Research aim } & 8\end{array}$

$2 \quad$ Materials and Methods $\quad 9$

2.1 Sample location \& organisms

$\begin{array}{ll}2.2 & \text { Experimental set-up }\end{array}$

2.3 Analysis 11

2.3.1 Environmental parameters 11

2.3.2 Mussel related biotic parameters 11

2.3.3 Seaweed productivity and C:N analysis 12

2.3.4 Calculations 12

$\begin{array}{lll}2.3 .5 & \text { Statistics } & 13\end{array}$

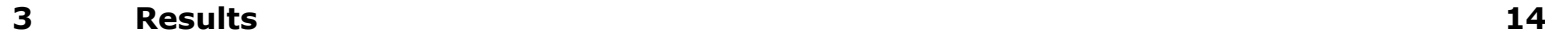

$\begin{array}{lll}3.1 & \text { Environmental parameters } & 14\end{array}$

$\begin{array}{lll}3.2 & \text { Mussel related biotic parameters } & 17\end{array}$

3.3 Pre-trial: mussel Dissolved Inorganic Nutrient excretion 19

$\begin{array}{ll}3.4 & \text { Ulva spp. productivity in monoculture and co-cultivation }\end{array}$

$\begin{array}{lll}3.5 & \text { Nutrient uptake Ulva-mussel experiment } & 21\end{array}$

$4 \quad$ Discussion and recommendations $\quad 24$

$\begin{array}{lll}4.1 & \text { Main outcomes } & 24\end{array}$

$\begin{array}{lll}4.2 & \text { Benefits of Ulva spp. and mussel co-cultivation } & 24\end{array}$

\begin{tabular}{ll}
4.3 & Relevance for commercial cultivation \\
\hline
\end{tabular}

$\begin{array}{lll}4.4 & \text { Recommendations } & 26\end{array}$

$\begin{array}{llr}5 & \text { Conclusion } & 27\end{array}$

$\begin{array}{llr}6 & \text { Quality Assurance } & 28\end{array}$

$\begin{array}{lr}\text { References } & 29\end{array}$

$\begin{array}{lr}\text { Justification } & 32\end{array}$ 


\section{Summary}

Seaweed and mussels are both important organisms used for aquaculture and often coexist in marine ecosystems. Amongst the many interactions between these two organisms is the potential for seaweed to benefit from additional nutrients (in particular ammonium) excreted by mussels. In addition, in mussel cultivation systems where the shellfish live in high densities, seaweed growth and production can be stimulated by the nutrient excretion from bivalves. Here we investigate cocultivation of the green macro-algae Ulva lactuca and Mytilus edulis (blue mussels) to see whether cocultivation with mussels increases Ulva production. Mesocosm experiments in which the Ulva lactuca and blue mussels were grown in combination as well as separately were conducted and production, $\mathrm{C}: \mathrm{N}$ ratio of the Ulva biomass and nutrient uptake were determined. No significant differences in production rates were found between Ulva cultivated in monoculture or co-cultivated with blue mussels. The specific growth rate of Ulva was $7.7 \pm 0.86$ and $7.8 \pm 0.89 \% \mathrm{DW} \mathrm{d}^{-1}$ in mono and seaweed mussel co-cultivation respectively. The $\mathrm{C}: \mathrm{N}$ ratio of the Ulva biomass (tanks containing only seaweed) measured at the start of the experiment $(31 / 07 / 2018)$ was $17.2(S D=2.35)$. This result was supported by the comparable C:N ratio of the Ulva biomass and no significant difference in ammonium uptake between both treatments (with and without mussels). Although an initial increase in ammonium concentration was detected by the addition of blue mussels, the nutrient uptake experiment in combination with Ulva did not show significant differences in the uptake of ammonium by Ulva cultivated in combination with mussels as opposed to Ulva cultivated by itself. However, a net increase in ammonium uptake by Ulva in combination with mussels as opposed to the uptake of ammonium in Ulva tanks without mussels was not ruled out. Moreover, the tanks containing only mussels did not show increased ammonium concentrations. It remains unknown why no enhanced ammonium concentrations were observed during the end of the experiment, and whether or not this has occurred throughout the experimental period, subsequently leading to little variation in growth and $\mathrm{CN}$ ratios between mono- and co-culture treatments. Although these results do not evidently demonstrate an advantage of seaweed cultivation in combination with mussels they do not rule out potential benefits from combined macroalgae- shellfish production. 


\section{Introduction}

\section{$1.1 \quad$ Background}

Mussel farming and seaweed farming are fast-growing sectors worldwide (Wijsman et al., 2019). Both mussels and various seaweed species can be grown on similar basic longline structures and several reasons exist to integrate the cultivation of these two crops. 1) better space utilization of limited permitted sites, 2) shared use of the capital costs of expensive anchors, lines and buoys, 3) better risk management via crop diversification. The additional benefits of using multiple complementary nutrient bio-extractive crops are improved ecosystem services such as (i) improved water quality, (ii) provision of structure resulting in nursery and foraging habitat for other species, and (iii) a sustainable seafood supply (Rose et al., 2015). Co-cultivation of seaweed and shellfish is often mentioned as a multi-use approach to efficiently use space in offshore wind parks (Michler-Cieluch \& Kodeih, 2008, van den Burg et al., 2017).

Moreover, seaweed and shellfish often co-exist in marine ecosystems and display multiple interactions. Seaweeds use the supply of nutrients available in seawater for growth just like unicellular algae (phytoplankton), a major food source for shellfish, do. Nitrogen (especially ammonium) is an important component produced by shellfish that macroalgae could benefit from. In the marine environment dissolved nitrogen is also available as nitrate $\left(\mathrm{NO}_{3}\right)$. Algae are able to utilize both forms of nitrogen but show a preference for ammonium $\left(\mathrm{NH}_{4}\right)$, since the uptake of ammonium requires less energy (ATP). Marine bacteria transform ammonium into nitrate, which means ammonium is often limited in waterbodies. The ammonium produced by mussels could therefore stimulate macroalgae growth. It has been suggested that seaweed can benefit from the excess ammonium excreted in IMTA systems by shellfish (Ajjabi et al., 2018, Bouwman et al., 2011a, Mao et al., 2009a) and fish (Buschmann et al., 2009, Sanderson et al., 2008). As opposed to unicellular algae, seaweed is capable to store nitrogen, which makes seaweed as a group suitable to grow under varying nutrient conditions that occur naturally as well as a result of the components produced by shellfish. In addition, shellfish improve visibility by filtering phytoplankton and other organic and inorganic material from the water column. The improved transparency can in turn positively affect seaweed growth in deeper water. Moreover, positive interaction of co-existence of seaweeds with shellfish have been claimed as mussel excretion nutrients can be exploited as a resource input (Ajjabi et al., 2018, Bouwman et al., 2011a, Mao et al., 2009a), reducing the risk of eutrophication (Bouwman et al., 2011b, Mao et al., 2009b). On the other hand, when seaweed production results in a strong decrease in nutrient concentration shellfish growth might be impaired. This is due to the reduced primary production that is limited by low nutrient availability, lower light availability by shading of macroalgae or high grazing pressure from filter-feeders. In an ecosystem where primary production is limited by nutrients, the nutrients utilized by seaweed are no longer available for unicellular algae, the feed supply for shellfish. This could potentially result in competition between seaweed and shellfish production in these systems. In this context it is also important to underline the differences in seasonality between seaweeds and phytoplankton (depending on the seaweed species).

\subsection{Ulva nutrient dynamics and productivity}

From May onwards, decrease of diatom biomass in the Oosterschelde is assumed to be a result of nutrient limitation (Bakker et al., 1994). Low ambient total ammonium nitrogen (TAN, the amount of $\mathrm{NH}_{4}$ and $\mathrm{NH}_{3}$ in the water) concentrations in the Oosterschelde are assumed to be the limiting factor for summer seaweed such as Ulva spp. Mean TAN concentration recorded at a sampling station nearby

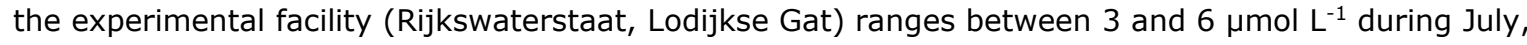
August and September. If Ulva spp. is nitrogen limited (de Vries, 2014), it might benefit from nutrient- $\mathrm{N}$ excretion. But if $\mathrm{N}$ is not limiting, $\mathrm{NH}_{4}$ excretion might lead to higher growth as a result of 
provision of an energy efficient $\mathrm{N}$-source. Therefore, it is hypothesized that Ulva spp. productivity rates (Table 1 ) will be positively correlated with increased $\mathrm{N}$-flux by mussel co-cultivation.

In addition, higher ammonium-N flux is expected to cause a shift from nutrient to light limited Ulva spp. growth, as was for example shown for experiments with the red algae Gracilaria tikvahiae (Lapointe \& Duke, 1984) (Fig. 1). The C:N ratio (ratio of carbon over nitrogen) in tissue can be used to determine if macroalgae are $\mathrm{N}$ limited (Hurd, 2014). High C:N ratio indicates $\mathrm{N}$-limitation because of a decrease in amino acids and proteins and an increase in carbohydrates (Björnsäter \& Wheeler, 1990). RuBPcase, an enzyme involved in fixing $\mathrm{CO}_{2}$ in plant tissue, is also $\mathrm{N}$-dependent, with a positive correlation under $\mathrm{N}$-sufficient and a negative correlation under $\mathrm{N}$-limited conditions (Duke et al., 1986). In sub-tropical cultivated green macroalgae such as Ulva lactuca (Neori et al., 1991a) and Ulva rigida (Pinchetti et al., 1998), high C: $N$ ratio in biomass is used as an indication of $N$-limitation; $U$. rigida $\mathrm{C}: \mathrm{N}$ ratio reduced from 35:1 to 5:1 when changing from nitrogen starvation to enrichment. In general, $\mathrm{C}: \mathrm{N}$ values close to 10 have been described as optimal or normal for the nitrogen status of algae and a ratio higher than 10 indicates $\mathrm{N}$-limitation (Lapointe et al., 1976). However, others indicate $\mathrm{C}: \mathrm{N}$ ratio of 18 as average for all macroalgae, and describe $\mathrm{C}: \mathrm{N}$ ratios $>20$ indicate possible $\mathrm{N}$ limitation (Hurd, 2014). C:N ratios below $>17$ have been measured for Ulva spp. during summer conditions, and values in August were higher compared to September (Buisman 2018), indicating that nitrogen limitation may occur in summer in the Oosterschelde.

Ulva spp. generally shows preferred uptake of ammonium-N above NO3-N, although both $U$. rigida and $U$. lactuca are able to utilize both nitrate and ammonium (Table 2). Ammonium is suggested to require less ATP compared to $\mathrm{NO}_{3}$ (Fujita, 1985). Therefore, $\mathrm{NH}_{4}{ }^{+}$or total ammonium nitrogen (TAN) is considered the preferred Ulva spp. N-source. This is confirmed by higher uptake rates of TAN when compared to nitrate $\left(\mathrm{NO}_{2}\right)$ (Cohen \& Neori, 1991a, Cohen \& Fong, 2004, Fujita, 1985). However, this pattern is not empirically found in all Ulva species. For example, the opposite was found for $U$. rigida that showed a preference for $\mathrm{NO}_{3}$ (Lavery et al., 1991b).

Table 1: Ulva spp. productivity as reported in literature in temperate, northern conditions

\begin{tabular}{llll}
\hline Ulva spp. species & Unit & Productivity & Reference \\
\hline U. lactuca & SGR \% FW d & $1.6-6.3$ & (Robertson-Andersson et al., 2008b) \\
U. lactuca & SGR \% FW d & $7.4-17.9^{\#}$ & (Neori et al., 1991b) \\
U. curvata & SGR \% DW d & $9.5-28$ & (Duke et al., 1989) \\
U. lactuca & SGR \% DW d & $-0.3-11.3^{*}$ & (Bruhn et al., 2011) \\
U. lactuca & $\mathrm{kg} \mathrm{DW} \mathrm{ha-1} \mathrm{d}^{-1}$ & $-31-679^{*}$ & (Bruhn et al., 2011) \\
U. lactuca & $\mathrm{kg} \mathrm{DW} \mathrm{ha} \mathrm{d}^{-1}$ & $68-188^{*}$ & (Debusk et al., 1986) \\
U. lactuca & $\mathrm{kg} \mathrm{DW} \mathrm{ha-1} \mathrm{d}^{-1}$ & $22-327$ & (Groenendijk et al., 2016)
\end{tabular}

${ }^{*}$ Mean values as presented in the study

* Sub-tropical region, fertilized conditions

Table 2: Ulva spp. nitrogen uptake rates ( $\mu$ mol gram dry weight ${ }^{-1}$ hour ${ }^{-1}$ ) of Total Ammonium Nitrogen (TAN) and nitrate $\left(\mathrm{NO}_{3}{ }^{-}\right)$as reported in literature. When cells are left empty no information is available.

\begin{tabular}{llll}
\hline Species & TAN $^{a}$ & $\mathrm{NO}_{3}{ }^{-}$ & Reference \\
\hline Ulva rigida & $50^{*}-136^{*}$ & 64 & (Solidoro et al., 1997) \\
Ulva rigida & $250^{\#}-371^{\#}$ & 640 & (Lavery et al., 1991a) \\
Ulva lactuca & 440 & 820 & (Fujita, 1985) \\
Ulva lactucab & $50^{*}-252^{\#}$ & & (Cohen \& Neori, 1991b) \\
Ulva curvata & 250 & & (Rosenberg \& Ramus, 1982) \\
Ulva fasciata & & 30 & (Lapointe et al., 1976) \\
\hline
\end{tabular}

a TAN (Total Ammonium Nitrogen) uptake rate; ${ }^{\mathrm{b}}$ Sub-tropical region; * $\mathrm{N}$ sufficient; \# $\mathrm{N}$ limitation 


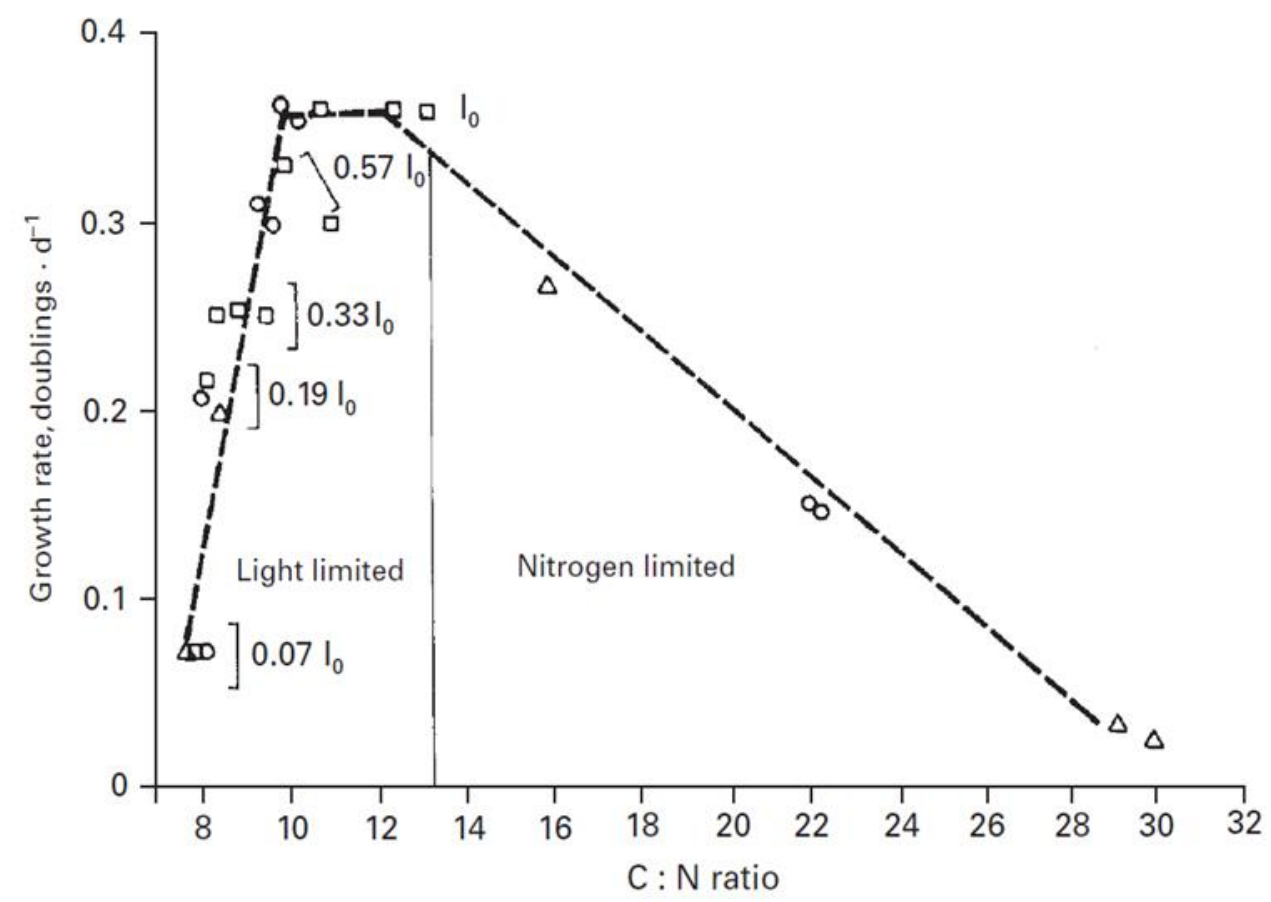

Figure 1: Correlation between growth rate of Gracilaria tikvahiae and tissue C:N ratio is dependent on light or nitrogen limitation (in Hurd et al., 2014, from Lapointe and Duke, 1985).

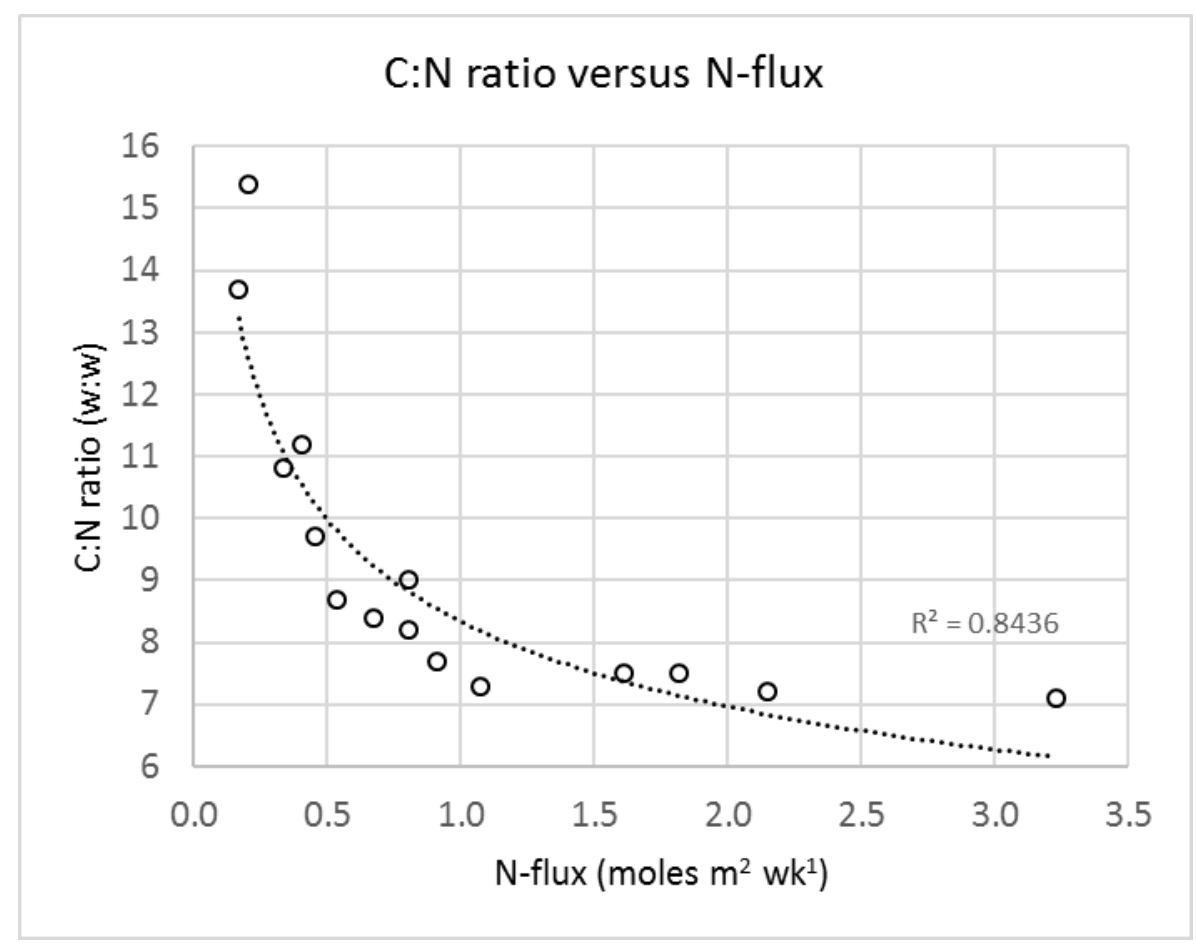

Figure 2: Correlation between C:N ratio in Ulva spp. and the $N$-flux in the water, data taken from (Neori et al., 1991a). The water $N$-flux is exponentially negatively correlated with C:N ratio in the seaweed biomass, indicating higher $N$ level. 


\subsection{Research aim}

In the context of a multi-use approach to increase efficient use of space in wind parks the question was posed whether co-production of seaweed and mussels is beneficial for Ulva growth through the uptake of metabolic byproducts (such as ammonium) excreted by mussels.

Growth enhancing effects of Mytilus edulis on the seaweed early nursery stages and grow out phase in the Baltic sea have been demonstrated (Rossner et al., 2014). However, benefits of co-cultivation for seaweed growth and mussels have not yet been thoroughly investigated. Empirical testing of seaweed variation and mussel co-cultivation will help to understand how circular thinking in aquaculture can be implemented resulting in maximum resource output.

The current study focusses both the potential benefit of co-cultivation. In order to do this, the following research questions were formulated:

Is co-cultivation with mussels (Mytilus edulis) potentially beneficial for Ulva spp. cultivation?

a) Does Ulva spp. productivity increase in co-cultivation with mussels?

b) Does Ulva spp. biomass $\mathrm{C}: \mathrm{N}$ ratio decrease in co-cultivation with mussels?

c) Do nutrient uptake rates of inorganic nutrients in the water column correlate to growth and $\mathrm{C}: \mathrm{N}$ composition of seaweed

To study these research aims, mesocosm experiments in which the seaweed species Ulva sp. and blue mussels (Mytilus edulis) were grown in combination as well as separately were conducted and nutrient uptake, production and $\mathrm{C}: \mathrm{N}$ ratio of the Ulva biomass were determined.

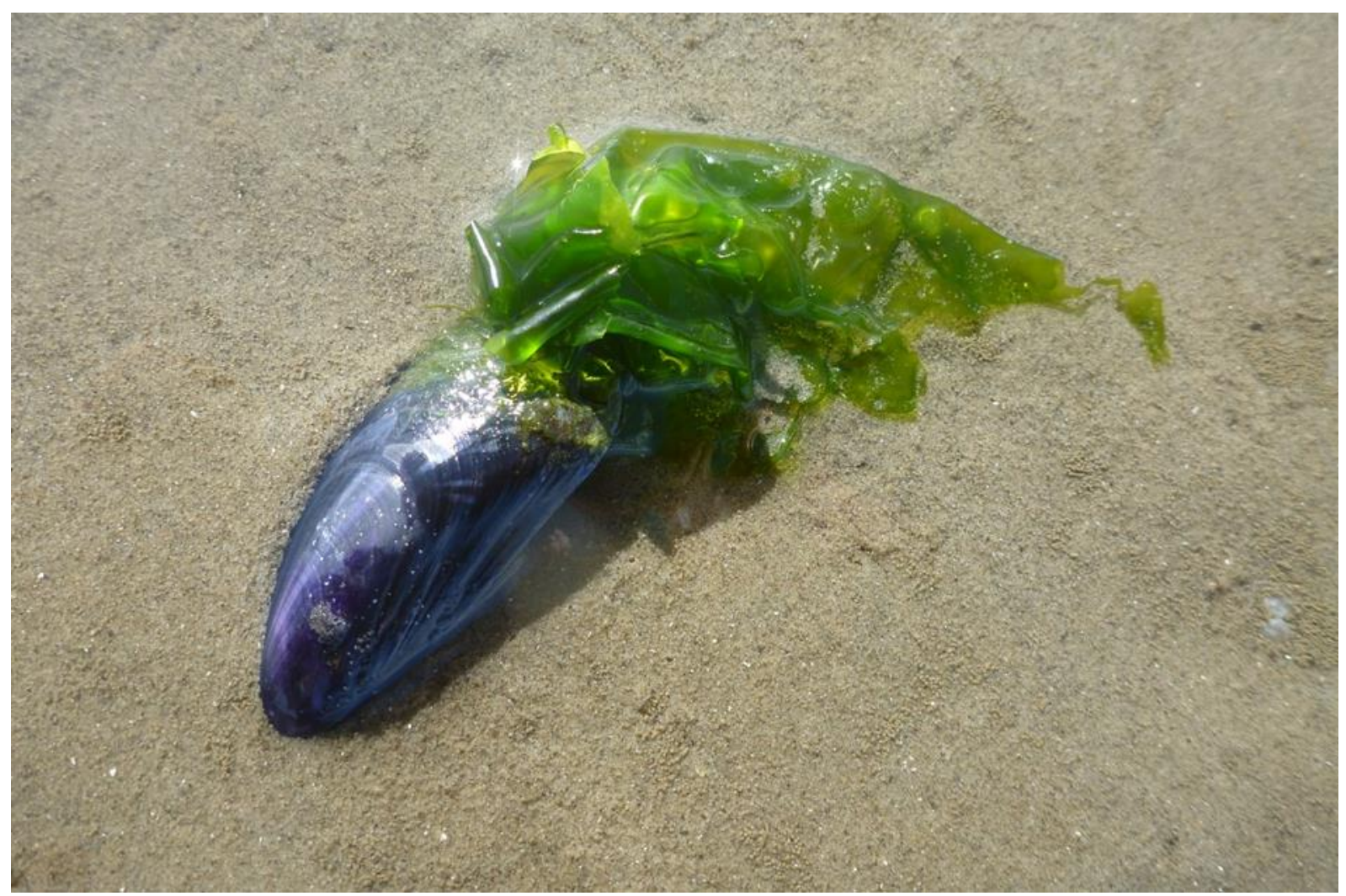

Figure 3: $\quad$ Mytilus edulis and Ulva sp. 


\section{Materials and Methods}

\subsection{Sample location \& organisms}

Ulva spp. were collected in April-May 2018 from 11 different locations (Fig. 4) in the Oosterschelde and at 2 locations in the Veerse Meer. A single piece of thallus (approx. size $100 \mathrm{~cm}^{2}$ ) was collected per location. This method ensured samples contained one single Ulva spp. strain. Locations were chosen at least $50 \mathrm{~m}$ apart in an attempt to collect different strains. The Ulva spp. collected from Heerenkeet (Fig. 4, sample location USHEE; strain was named "blue18") was successfully cultivated and used to compare Ulva spp. growth with and without mussels. Blue mussels (Mytilus edulis) of commercial size were obtained from commercial producer Prins \& Dingemanse. Model species Ulva lactuca is common from tropical to polar coastal marine systems, although the strains most likely vary among regions (Bruhn et al., 2011). Season and climate effectively influence macroalgae conditions for growth, effectively determining Ulva spp. growth rates and biochemical composition (Lamare \& Wing, 2001). The growth season of Ulva is in summer.

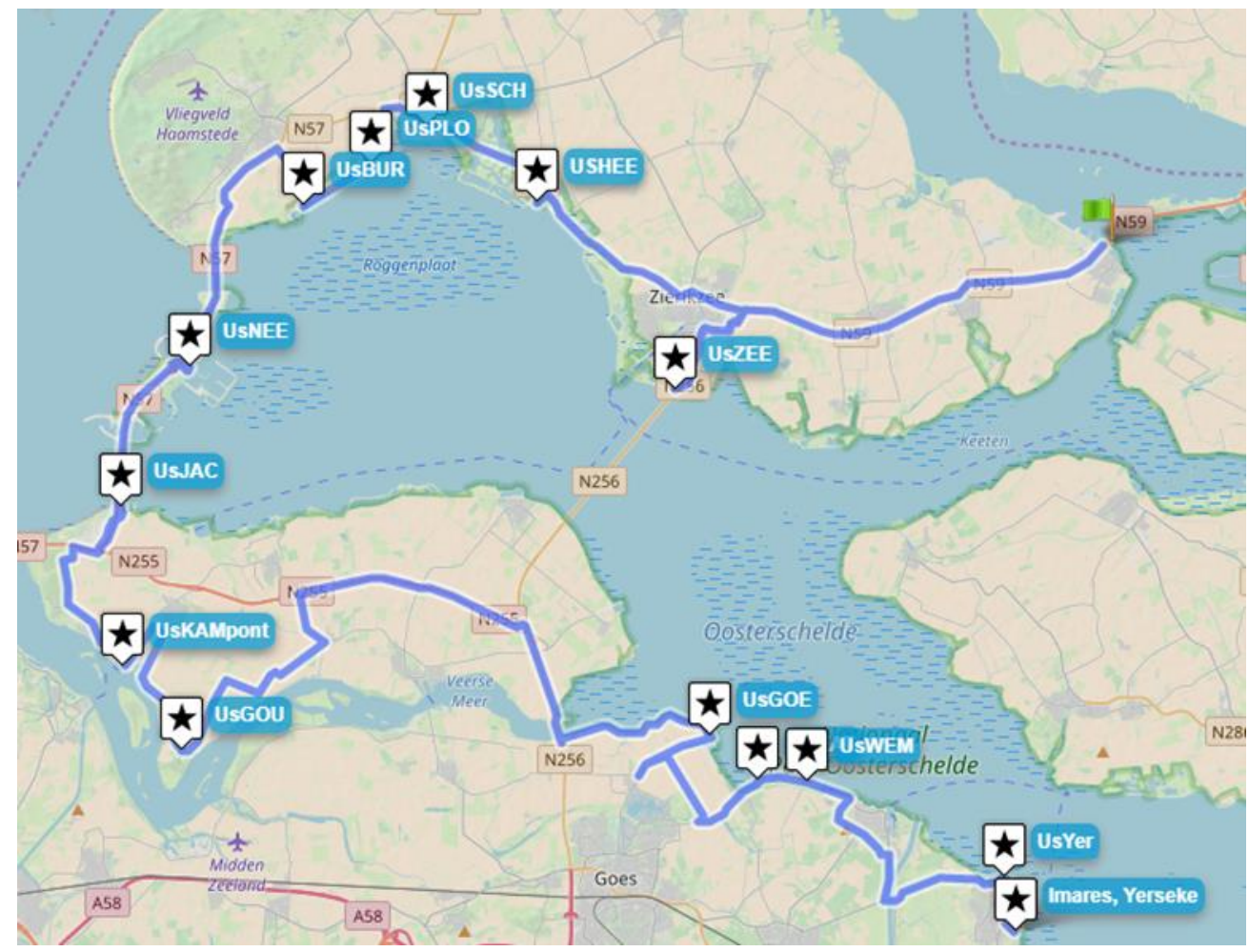

Figure 4: Sampling locations in 2018 in the Oosterschelde estuary and Veerse Meer and location of experimental set-up (Imares, Yerseke).

\subsection{Experimental set-up}

The experiment was conducted in July/August 2018 at the research facility of Wageningen Marine Research in Yerseke. Ulva was cultivated in outdoor, flow-through. The PCV tanks (400L, $90 \times 110 \times 40$ $\mathrm{cm}$ width $\mathrm{x}$ length $\mathrm{x}$ depth) were placed outdoor and connected in a flow-through set-up (Fig. 5). Tanks were continuously supplied with water from the Oosterschelde from a $10-15 \mathrm{~m}$ deep entry point (no nutrients added), and distributed via higher situated overflow tanks (headers) using tubing ( $\varnothing 15 \mathrm{~mm}$ ). Water exchange was kept constant at approximately 7 times tank volume $\mathrm{d}^{-1}\left(32.5 \mathrm{~mL} \mathrm{sec}^{-1}\right)$ by weekly measurements and fitted with an aeration system (PVC tubes) to ensure mixing inside the tanks. Tanks were cleaned every two weeks from fouling using a water vacuum cleaner and high-pressure cleaner (DiBo P50 WP, Nilfisk C 125.7-6 Home X-TRA). Netting and a bucket were fitted in front of the tank 
outflow to ensure Ulva remained in the tank and an UV filter (Auga UV-c PEHD 420) was placed before the outlet into the Oosterschelde to inactivate and reduce excessive Ulva spores and material.
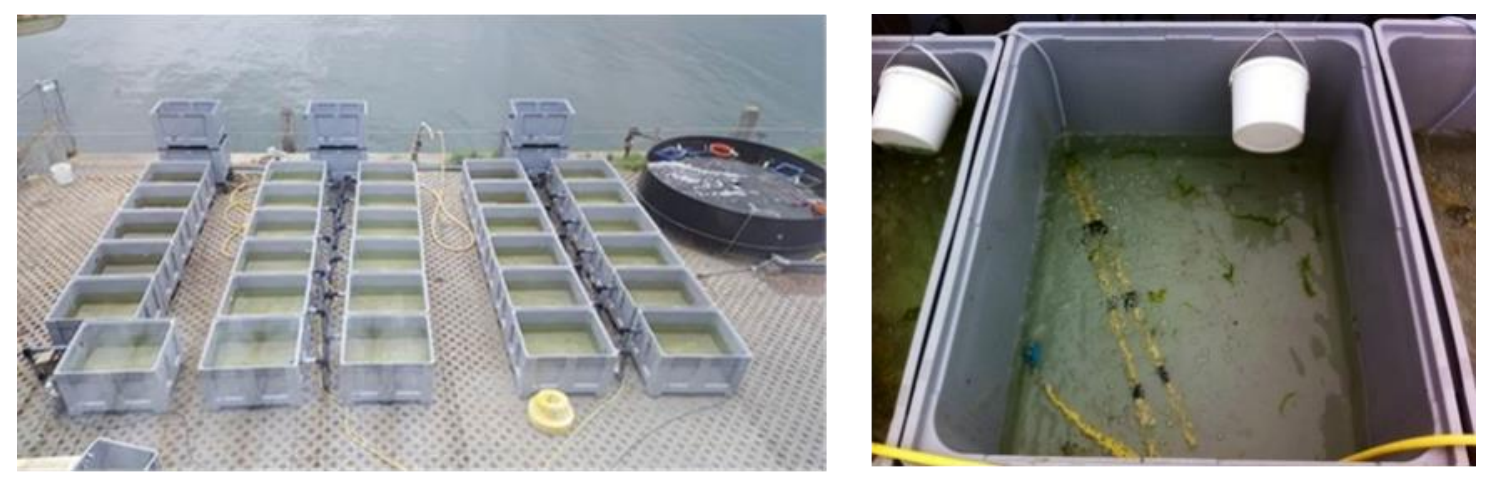

Figure 5: Experimental set-up of flow-through cultivation tanks (left); First cultivation of sampled single Ulva spp. thalli (right).

The experiment was designed to compare Ulva spp. growth and nutrient uptake rates in monoculture or in co-cultivation with blue mussels (Fig. 6). Control tanks (no seaweed, no mussels) were added to the experimental design to determine the effect of natural accumulating fouling organisms on nutrient availability. A genetically homogeneous Ulva spp. strain was used in this set-up in order to minimize interaction effects of growth and/or nutrient uptake variation between strains. The Ulva spp. used was simultaneously re-stocked with a fixed amount of fresh weight (FW) cultivated Ulva spp. in additional tanks (Table 3). Blue mussels were placed in a separate pvc tray at the bottom of the tank. Mussels were left to acclimatize for at least 24 hours. Additional tanks that only contained mussels $(n=4)$ were included to determine the effect of mussel presence.

A pre-trial was performed on $20 / 06 / 2018$ to determine the amount of mussels necessary to obtain sufficient levels of ammonium in the tanks. In order to do this 2, 2.5 and $4 \mathrm{~kg} \mathrm{FW}$ mussels were added to 3 tanks and DIN concentration was measured after 24 hours acclimatization to confirm the increase of ammonium- $\mathrm{N}$ flux by mussel presence (see nutrient analysis for more details). The pre-trial was conducted with similar flow through $\left(32.5 \mathrm{~mL} \mathrm{sec}^{-1}\right)$.

Each 'mussel tank' and 'seaweed plus mussel tank' contained 4 kg FW commercial mussels (length: 5.54 $\pm 0.54 \mathrm{~cm}$ ). Subsequently, $280 \mathrm{~g} \mathrm{FW}$ Ulva spp. was added to 4 of these tanks. The replicate tanks of each treatment (control, seaweed, mussels, mussels + seaweed) were organized in a randomised way to avoid potential effects of the header and shading from adjacent buildings. The experiment ran for four weeks (from 31/07/2018 until 28/08/2018). At the end of the experiment DIN concentration was measured again in order to get an indication of DIN uptake (see nutrient analysis for more details).

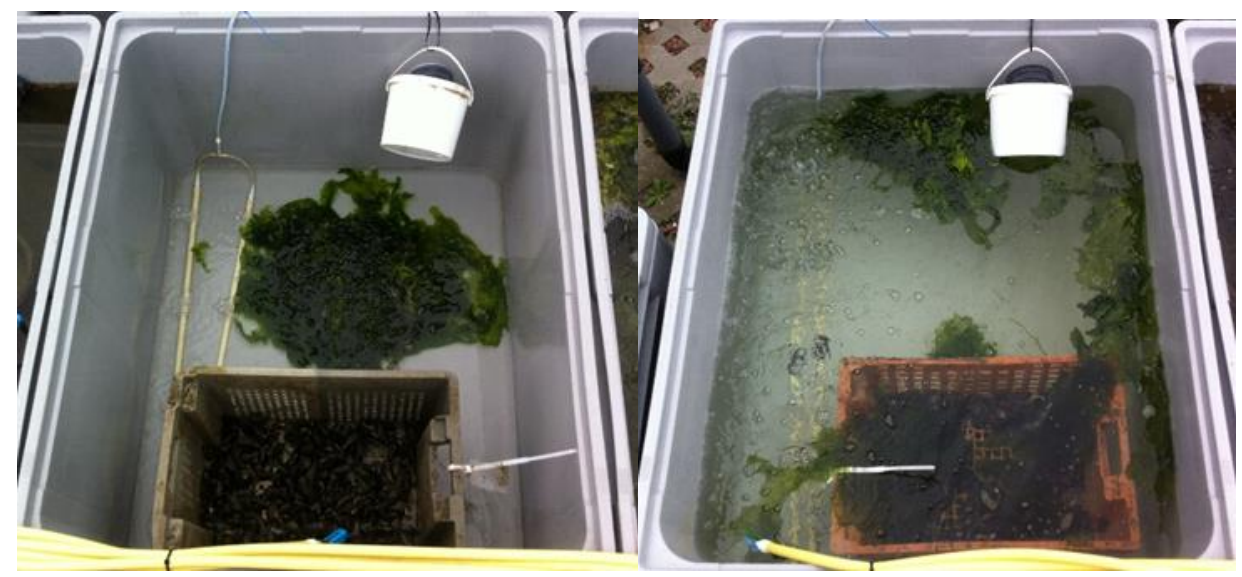

Figure 6: Experimental tanks: trays with blue mussels placed on the bottom of the Ulva tanks to imitate co-cultivation system conditions. Mussel trays were elevated using bricks to prevent detritus to accumulate inside the tray. 


\subsection{Analysis}

\subsubsection{Environmental parameters}

\section{Temperature and photon irradiance}

Temperature $\left({ }^{\circ} \mathrm{C}\right)$ and light intensity $\left(\mu \mathrm{mol} \mathrm{m} \mathrm{m}^{-2} \mathrm{sec}^{-1}\right)$ were logged continuously in control tanks without mussels or seaweed (HOBO logger, $15 \mathrm{~min}$. interval). Water quality was checked weekly by determining temperature, $\mathrm{pH}$ and Dissolved Oxygen in each tank. In addition, biweekly monitoring of tank fouling was done using a qualitative scale of measurement with four levels of tank fouling (no, light, medium, heavy).

\section{Dissolved Inorganic Nutrient concentrations}

The nutrient concentration in the header tanks were determined at a standardised time (11 AM) by taking water samples for Dissolved Inorganic Nutrients: ammonium $\left(\mathrm{NH}_{4}^{+}\right)$, nitrite $\left(\mathrm{NO}_{2}\right)$, nitrate $\left(\mathrm{NO}_{3}\right)$, phosphate $\left(\mathrm{PO}_{4}\right)$ and silica $\left(\mathrm{SiO}_{2}\right)$. Nutrient uptake was determined: 1 ) prior to the experiment to confirm the increase of ammonium- $\mathrm{N}$ flux by mussel presence, and 2) at the end of the experiment to get an indication of DIN uptake (point measurement). DIN water samples were taken from the in- and outflow in each tank. Water samples $(10 \mathrm{ml})$ were filtered $(0.45 \mu \mathrm{m})$, and stored at $-20^{\circ} \mathrm{C}$ prior to analysis. DIN analyses $\left(\mathrm{NH} 4+, \mathrm{NO} 3, \mathrm{NO} 2, \mathrm{PO}_{4}\right.$ and $\left.\mathrm{SiO}_{2}\right)$ were performed at the research facility of the Royal Netherlands Institute for Sea Research (NIOZ) in Yerseke using an autoanalyzer. These were compared to ambient Total Ammonia Nitrogen (TAN; total ammonia and ammonium combined) concentration measurements from a nearby sampling station (Lodijkse Gat) (Fig. 9).

\subsubsection{Mussel related biotic parameters}

\section{Organic fouling}

Fouling by organisms inside the cultivation tanks in between fortnightly cleaning was monitored by scoring the level in categories: no fouling, light, medium and heavy.

\section{Mussel length and yield}

Individual mussel length was measured before and after the experiment. The tanks containing mussels were checked regularly to ensure mussels were still alive. The total amount of mussels was weighed and individuals were counted at the beginning and at the end of the experiment.

\section{Suspended Particulate Matter (SPM)}

Sufficient food availability for the mussels was determined by weekly measuring the Suspended Particulate Matter (SPM) in the inflow of tanks from experiment 2 using pre-burned filters $(3 \times 2 \mathrm{~L}$, Whatman GF/C $47 \mu \mathrm{m})$. After filtration $(2 \mathrm{~L})$, filters were rinsed with fresh water $(3 \times 50 \mathrm{ml})$ and dried $\left(70^{\circ} \mathrm{C},>30 \mathrm{~h}\right)$. Filters were weighed $\left(\mathrm{W}_{70 \mathrm{C}}\right)$, placed in a furnish $\left(450^{\circ} \mathrm{C}, 6 \mathrm{~h}\right)$ and weighed again $\left(\mathrm{W}_{450 \mathrm{C}}\right)$. 


\subsubsection{Seaweed productivity and C: $\mathrm{N}$ analysis}

To determine productivity, seaweed biomass was weighed every two weeks by collecting all biomass per tank (Fig. 7). To prevent potential damage to the Ulva by centrifuge, subsamples of $280 \mathrm{~g}$ FW were dabbed dry using paper, and this biomass was used to re-stock. The remaining biomass was dried using a centrifuge to get rid of excess water and to determine FW growth rate. Dry weight (DW) and ash free dry weight (AFDW) were determined by subsample using the oven ( $70^{\circ} \mathrm{C}, 24 \mathrm{~h}$ ), and muffle furnace $\left(450^{\circ} \mathrm{C}, 6 \mathrm{~h}\right)$.

To determine the $\mathrm{C}: \mathrm{N}$ ratio of the Ulva biomass subsamples were dried $\left(40^{\circ} \mathrm{C}\right)$ for 48 hours and processed using a homogenizer. The $\mathrm{C}: \mathrm{N}$ ratio was determined according to the DUMAS principle using a isotope-ratio mass spectrometry (IRMS) element analyser at the department of animal nutrition (Wageningen University \& Research).

\subsubsection{Calculations}

Water temperature $\left({ }^{\circ} \mathrm{C}\right)$ and light intensity $\left(\mu \mathrm{mol} \mathrm{m} \mathrm{m}^{-2} \mathrm{sec}^{-1}\right.$ ) measured by HOBO loggers resulted in peak values when loggers were taken out from the water. Moving averages were applied to smoothen the disrupting peak values using the rollmean $(k=15)$ function in $R$, calculating average daily values. Ammonia- $\mathrm{N}$ flux was calculated using the $\mathrm{NH}_{4}{ }^{+}$concentrations in the header tanks multiplied by the water exchange rate using the following formula (Fujita, 1985, Neori et al., 1991b):

$$
\text { Flux }\left(\mu \mathrm{mol} \mathrm{h} \mathrm{h}^{-1}\right)=[\text { DINinput }] * \text { Water exchange rate }
$$

Where $[T A N]=$ ammonia- $N$ concentration in the header tanks $(\mu \mathrm{M})$, water exchange rate $=$ number of times water is exchanged in the tanks $\left(\mathrm{d}^{-1}\right)$. Uptake was quantified as the difference between in- and outflow DIN concentrations in the tanks, and expressed as relative measure using the following formulas:

$$
\begin{gathered}
\text { Uptake }\left(\mu \mathrm{mol} \mathrm{h}^{-1}\right)=\left([D I N]_{I N} * \text { flow }\right)-\left([D I N]_{\text {OUT }} * \text { flow }\right) \\
\operatorname{Uptake}(\%)=\frac{[D I N]_{I N}-[D I N]_{\text {OUT }}}{[D I N]_{I N}} * 100
\end{gathered}
$$

Ulva spp. growth was expressed in fresh weight (FW) and calculated as productivity (D'Elia \& DeBoer, 1978) and specific growth rate (SGR):

$$
\begin{aligned}
& \text { Seaweed productivity }(g)=\mathrm{W}_{t}-\mathrm{W}_{\mathrm{re}-\text { stocked }} \\
& \qquad S G R\left(\% d^{-1}\right)=100 *\left[\ln \left(\frac{W_{t}}{W_{0}}\right)\right] / t
\end{aligned}
$$

where $W_{0}$ is the initial biomass and $W_{t}$ is the biomass after $t$ days. Variations in growth periods were accounted for by comparing productivity between years by only comparing weeks when both experiments were running (week 29 - 39). 
Furthermore, dry weight (DW) and ash free dry weight (AFDW) of seaweed biomass were calculated using the following formulas:

$$
\begin{gathered}
\text { Dry Weight }(g D W)=\mathrm{W}_{70 C} \\
\text { Ash Free DryWeight }(g A F D W)=\mathrm{W}_{70 C}-\mathrm{W}_{450 \mathrm{C}}
\end{gathered}
$$

In experiment 2, suspended particulate matter (SPM) in water inflow was monitored, and water fraction Organic Material (\%OM) was calculated using the following formula:

$$
\text { Fraction Organic Material }(\% O M)=\frac{A F D W}{D W} * 100 \%
$$

\subsubsection{Statistics}

Data was statistically analysed using the R software ( $R$ Core Team, 2017). After the assumption of normality was checked for all parameters tested by one-way Analysis of Variance (ANOVA) and data was transformed when variation in the data deviated from normal distribution. If assumption of normality remained violated, alternative non-parametric methods were used (Kruskal-Wallis rank test). Differences between treatment groups were analysed with multiple comparison post-hoc tests (Tukey's tests) at $\mathrm{p}<0.05$. 


\section{Results}

\subsection{Environmental parameters}

In Table 3, environmental conditions are listed for the following tanks: controls, with Ulva, with mussels and tanks with mussels combined with Ulva. Environmental water parameters (temperature, $\mathrm{pH}$, dissolved oxygen concentration) were not affected by the presence of mussels in the co-cultivation set-up. However, oxygen levels were slightly higher in tanks containing Ulva and tanks containing Ulva in combination with mussels (Table 3). The mean water temperature measured in the control tanks from July until September 2018 was high compared to 2017 (2.8 and $3.3^{\circ} \mathrm{C}$ higher in August and September respectively) which is in line with the hot weather recorded in the Netherlands during the summer of 2018. Water temperature in the control tanks (400L) peaked at the end of July 2018 when day time irradiance reached a maximum light irradiation of $68550 \mu \mathrm{mol} \mathrm{m}^{-2} \mathrm{sec}^{-1}$ (Fig. 7 and 8). A maximum of $35.5^{\circ} \mathrm{C}$ was found in the tanks at the start of August. During two periods (end of July and beginning of August), the minimum night time water temperature in the tanks did not fall below $20^{\circ} \mathrm{C}$. In addition, the difference between maximum and minimum water temperature was larger during July when compared to August and September, indicating stronger daily fluctuations in water temperature. Figure 4 demonstrates differences in weather conditions between 2017 and 2018. The Ulva mussel co-cultivation was conducted in August 2018.

Mean TAN concentration in ambient Oosterschelde water was 3.6 and $5.8 \mu \mathrm{mol} \mathrm{L}^{-1}$ in August and September (Fig. 9). Mean $\mathrm{NO}_{3} / \mathrm{NO}_{2}$ concentration was 2.8 and $3.6 \mu \mathrm{mol} \mathrm{L}{ }^{-1}$ in August and September (Fig. 9). Ammonium concentrations in the header measured during the experiments all fall within the total ammonia nitrogen (TAN) concentration range measured at the nearby sampling station (Lodijkse Gat) during the period of 2010 - 2016 (Fig. 9). Therefore, mean ambient TAN concentration could be used as a proxy for nutrient inflow concentrations in the experiment in 2018. Mean TAN concentrations increased during the experimental period, with values ranging between 3 and $6 \mu \mathrm{mol} \mathrm{L}^{-1} \mathrm{~h}^{-1}$ in July, August and September (Rijkswaterstaat: waterinfo.rws.nl). Nitrogen flux in the Oosterschelde generally peaks early at the start of spring (February-March) and is lowest during summer (JulyAugust) (de Vries, 2014), reflecting the nutrient uptake by phytoplankton blooms. The average chlorophyll a concentration measured in the Oosterschelde at Lodijkse Gat (data from 2000-2016,

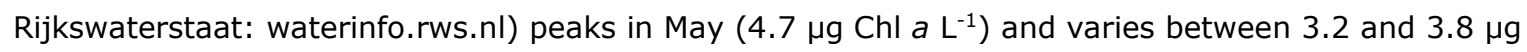
Chl $a \mathrm{~L}^{-1}$ in July and August (Fig. 10). 
Table 3: Environmental water parameters in 2018

Environmental parameters are: $\mathrm{pH}$; Temperature ( $\left.{ }^{\circ} \mathrm{C}\right) ; \mathrm{O}_{2}\left(\mathrm{mg} \mathrm{L}^{-1}\right)$; light intensity ( $\left.\mu \mathrm{mol} \mathrm{m}^{-2} \mathrm{sec}^{-1}\right)$ and Total Ammonia Nitrogen (TAN; $\left.\mu \mathrm{mol}-N^{-1}\right)$. Numbers $(n=4)$ are the mean $( \pm S D)$ of the weekly measurements in the tanks (control, ulva, mussel and combination mussel + Ulva (co)) except for TAN which was measured at nearby monitoring station, Lodijkse Gat, by Rijkswaterstaat (mean \pm SD, $n=1-4)$.

\begin{tabular}{|l|l|l|l|}
\hline & July & August & September \\
& 2018 & 2018 & 2018 \\
\hline $\mathrm{pH}$ control & $8.5 \pm 0.27$ & $7.9 \pm 0.22$ & $8.2 \pm 0.05$ \\
$\mathrm{pH}$ ulva & $8.6 \pm 0.23$ & $8.2 \pm 0.06$ & $8.5 \pm 0.27$ \\
$\mathrm{pH}$ mussel & - & $8.1 \pm 0.06$ & \\
$\mathrm{pH}$ co & - & $8.2 \pm 0.06$ & $18.8 \pm 0.31$ \\
\hline$T_{\text {control }}$ & $22.4 \pm 1.20$ & $23.0 \pm 0.95$ & $18.5 \pm 0.33$ \\
$\mathrm{~T}_{\text {ulva }}$ & $22.4 \pm 1.45$ & $22.8 \pm 0.82$ & \\
$\mathrm{~T}_{\text {mussel }}$ & - & $23.0 \pm 0.79$ & $10.1 \pm 0.23$ \\
$\mathrm{~T}_{\text {co }}$ & $9.1 \pm 0.83$ & $22.9 \pm 0.81$ & $10.6 \pm 0.50$ \\
\hline $\mathrm{O}_{2 \text { control }}$ & $10.9 \pm 0.70$ & $8.3 \pm 0.56$ & \\
$\mathrm{O}_{2}$ ulva & & $9.4 \pm 0.91$ & $119.7 \pm 231.8$ \\
$\mathrm{O}_{2 \text { mussel }}$ & - & $8.8 \pm 0.72$ & \\
\hline $\mathrm{O}_{2 \text { co }}$ & $283.1 \pm 423.7$ & $211.1 \pm 368.6$ & \\
\hline Light & $3.3 \pm 2.5$ & & \\
\hline$[$ TAN] & & & \\
\hline
\end{tabular}

\# Measured in control tanks only

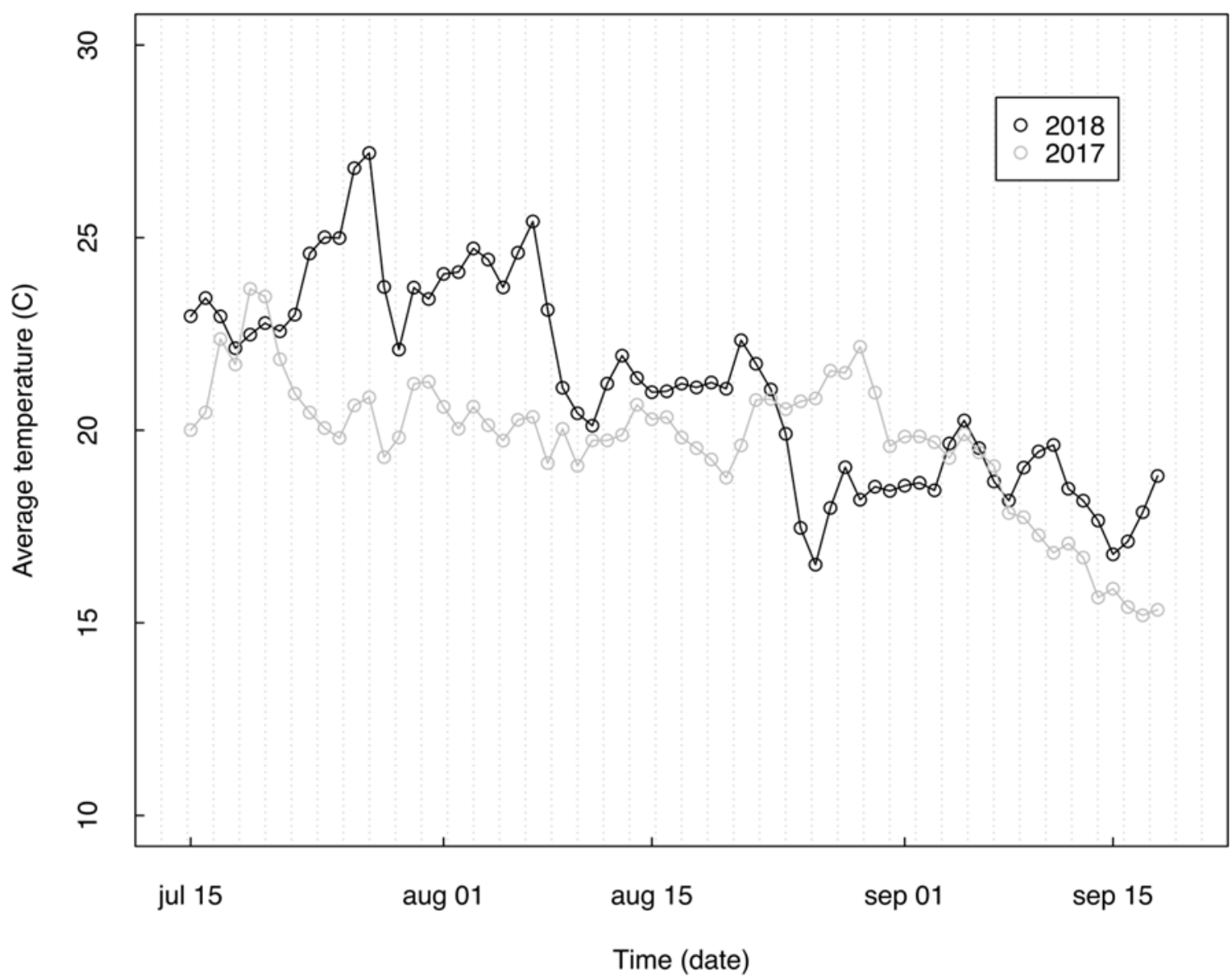

Figure 7: Average $(n=4)$ water temperature $\left({ }^{\circ} \mathrm{C}\right)$ measured in the control tanks in 2017 (light grey) and 2018 (dark grey). 


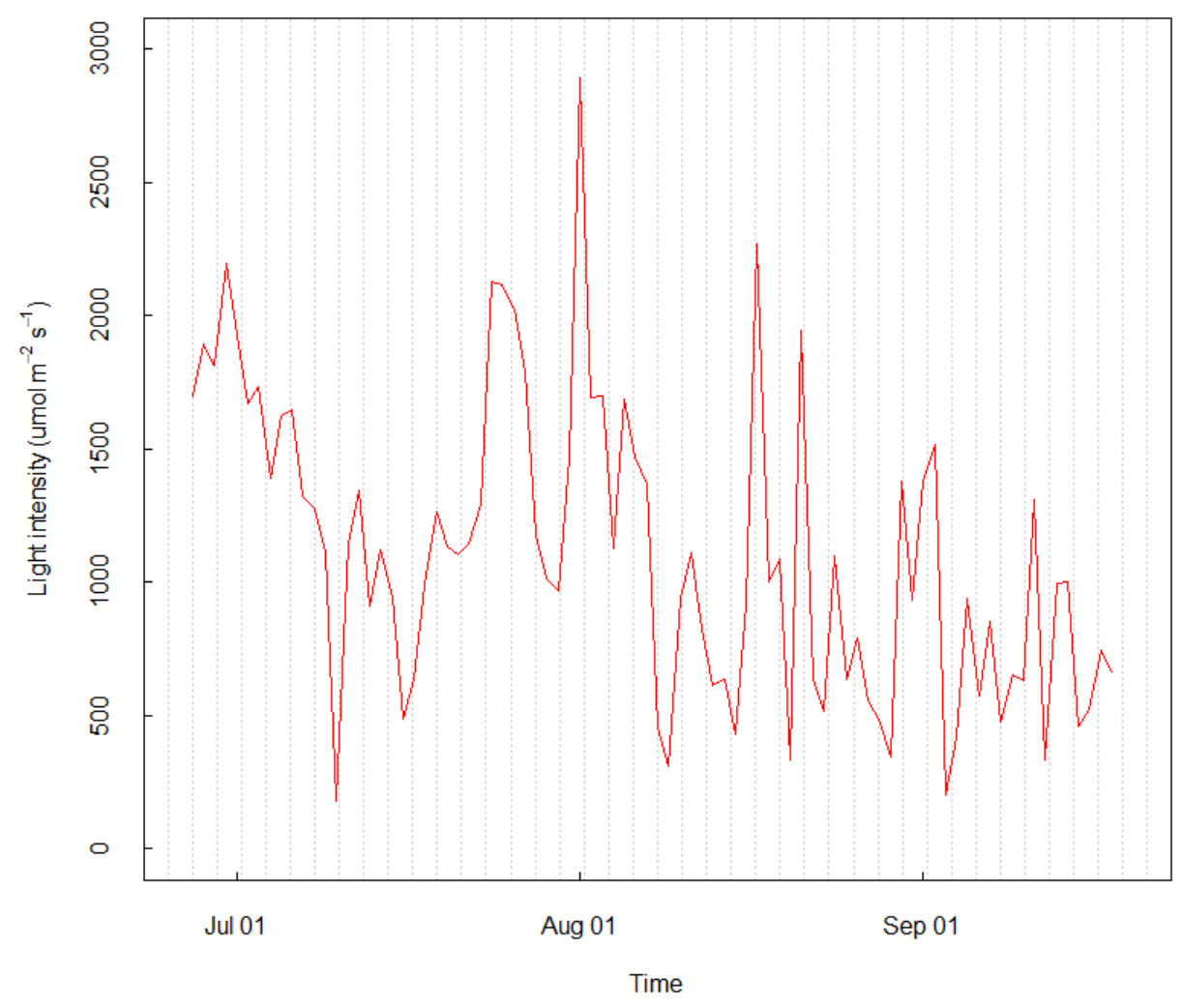

Figure 8: Daily moving average of maximum photon irradiance (measured in $\mu \mathrm{mol}$ photons $\mathrm{m}^{-2} \mathrm{~s}^{-1}$ ) in $2018(n=4)$.

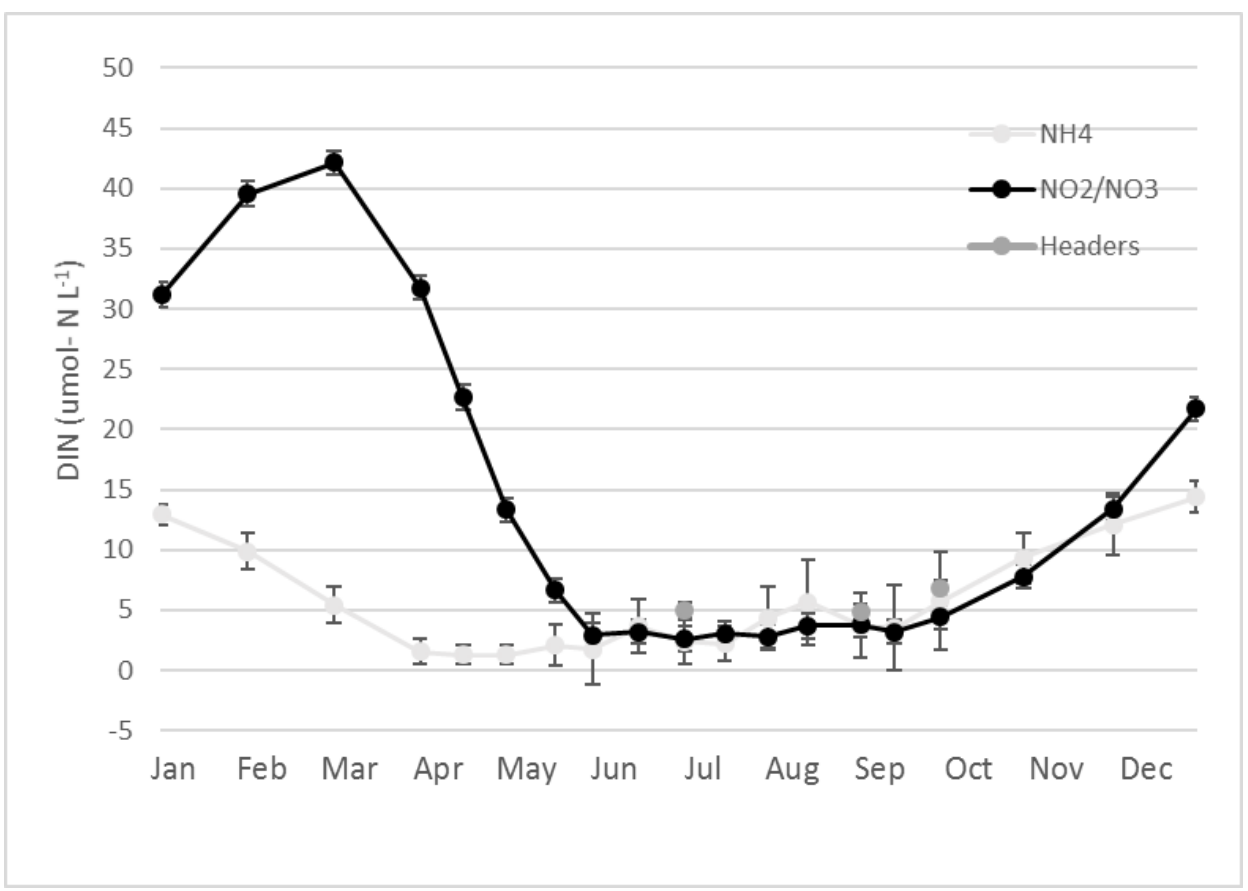

Figure 9: Mean dissolved inorganic nitrogen (DIN) concentration ( $\mathrm{NH}_{4}$ in light grey line, $\mathrm{NH}_{4}$ headers in dark grey, $\mathrm{NO}_{2} / \mathrm{NO}_{3}$ in black $\mu \mathrm{mol}-\mathrm{N} \mathrm{L}^{-1}$, mean $\pm \mathrm{SD}, n=7$ ) at Lodijkse Gat in the Oosterschelde 2010 - 2016 (waterinfo.rws.nl) and mean ammonium concentration measured in headers during the experiment (grey and black squares, $\mu \mathrm{mol}-N L^{-1}$, mean $\pm S D, n=1-5$ ) (this study). 


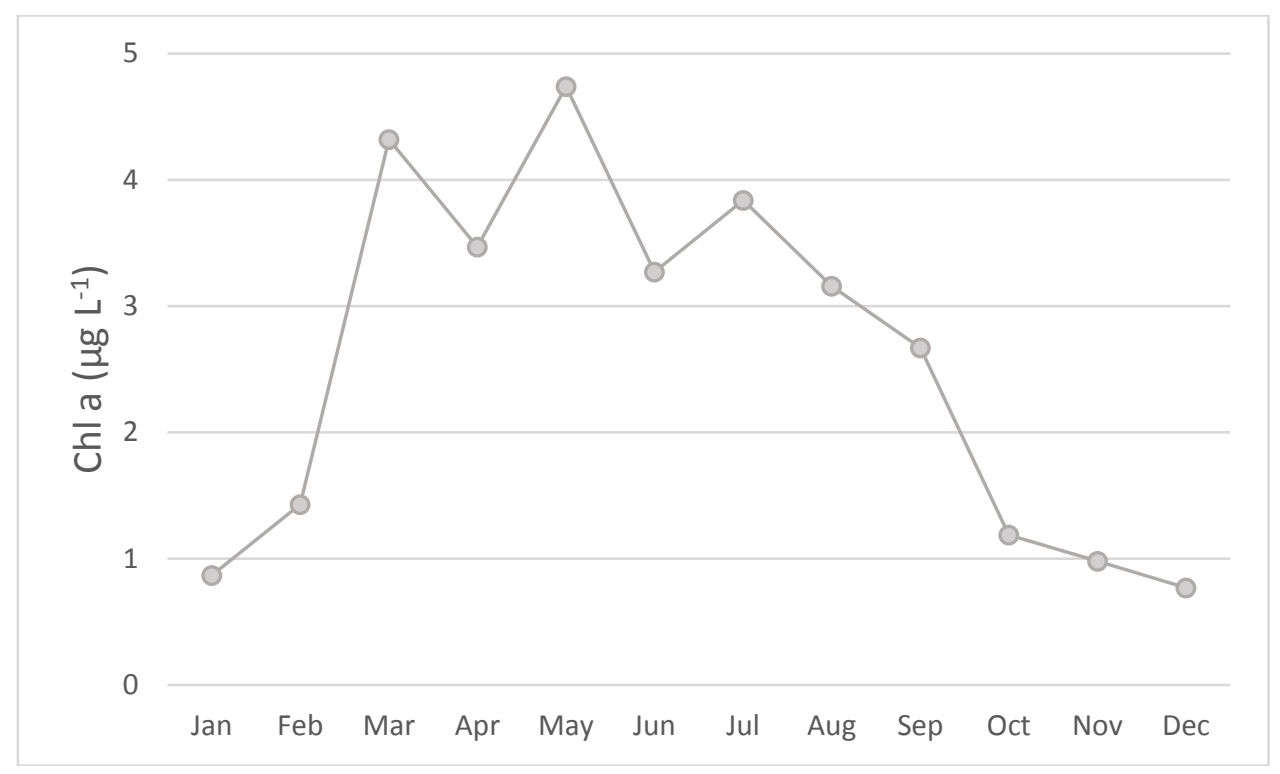

Figure 10: Chlorophyll a concentration (black line, $\mu \mathrm{g} \mathrm{Chl-a} L^{-1}$, mean, $n=7$ ) at Lodijkse Gat, the Oosterschelde, during 7 years: 2010 - 2016 (waterinfo.rws.nl).

\subsection{Mussel related biotic parameters}

The level of fouling by organisms inside the cultivation tanks in between fortnightly cleaning was monitored (Fig. 11). Most heavy organic fouling was detected in the control tanks. Tanks with mussels showed light to medium fouling, whereas tanks with both mussels and seaweed showed least fouling. Tanks containing only seaweed (Ulva strain blue) showed higher fouling without the addition of mussels. The content of the tank seems to be an important indicator for the appearance of microorganisms.

Mussel survival during the experiment was $>80 \%$ and equal between treatments resulting in a biomass reduction of mussels from 4 to $3.3 \mathrm{~kg}$ FW total weight. Individual mussel length was between 5 and $6 \mathrm{~cm}$ (placing them in the category of consumption size mussels) during the experimental period in both treatments (Table 4). No significant differences were found in length or weight between the start and the end of the experiment (after 5 weeks).

Suspended particulate matter (SPM) in unfiltered seawater from the Oosterschelde varied between 5.3 and $11.7 \mathrm{mg} \mathrm{L}^{-1}$, with an average of $25.1 \pm 0.05(\%)$ organic matter measured weekly during the experiment (Fig. 12). 


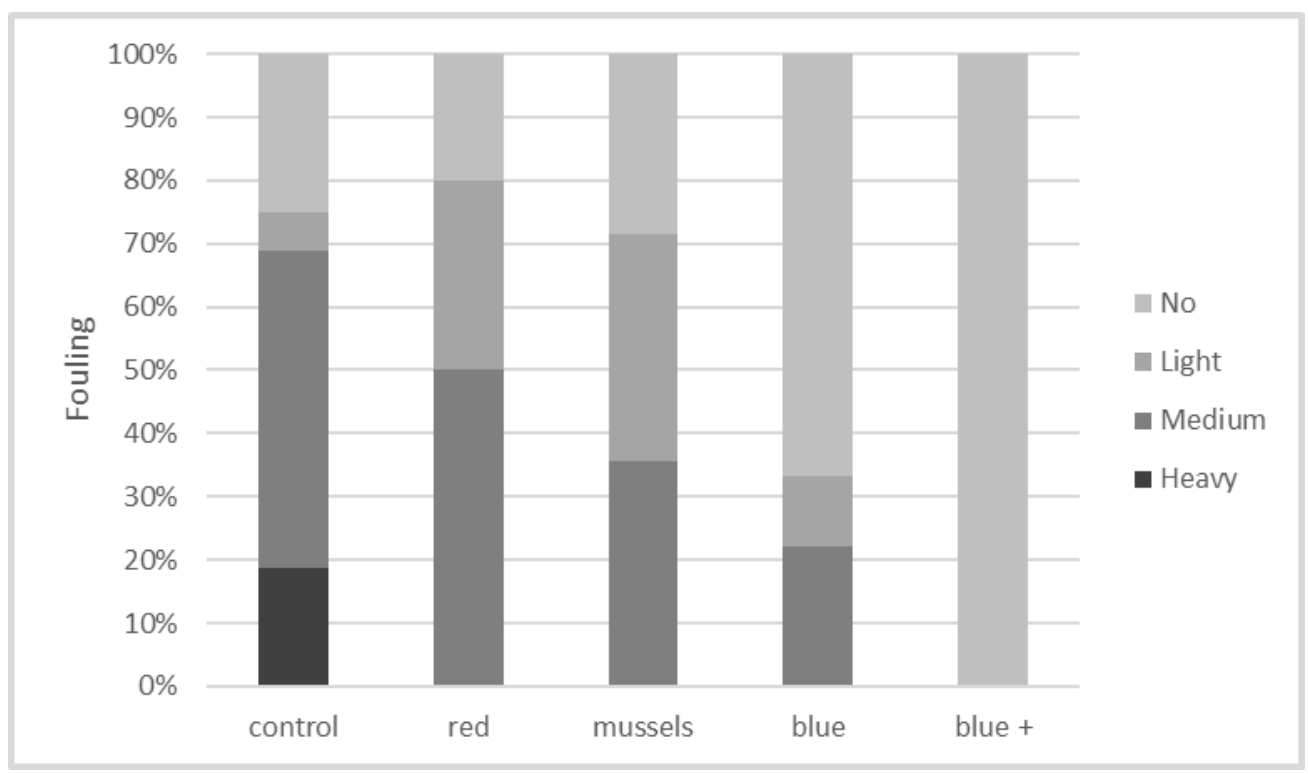

Figure 11: Tank fouling during the experiment, August 2018, week 31 - 35 ( $n=4)$. Red, blue and green denote names of different Ulva strains (only blue was used in this experiment), blue + denotes tanks with both Ulva and mussels. 
Table 4: Mussel parameters

Mussel survival (\% of initial number of specimens, mean $\pm S D, n=8)$, total weight (W) ( $\mathrm{kg}$, mean \pm $S D, n=8)$ and individual length $(L)(\mathrm{cm}$, mean $\pm S D, n=167-276)$ at start and end of the experiment for monoculture and co-cultivation.

\begin{tabular}{|c|c|c|c|}
\hline & Unit & Mussels only & $\begin{array}{l}\text { Ulva spp. and mussel co- } \\
\text { cultivation }\end{array}$ \\
\hline Survival & o of total \# specimens & $81 \pm 10$ & $89 \pm 11$ \\
\hline $\mathrm{W}_{\text {start }}$ & $\mathrm{kg}$ & $4.0 \pm 0.0$ & $4.0 \pm 0.0$ \\
\hline Wend & $\mathrm{kg}$ & $3.3 \pm 0.4$ & $3.3 \pm 0.0$ \\
\hline Lstart & $\mathrm{cm}$ & $55.2 \pm 3.2$ & $56.3 \pm 4.6$ \\
\hline Lend & $\mathrm{cm}$ & $56.2 \pm 1.9$ & $56.4 \pm 3.7$ \\
\hline
\end{tabular}

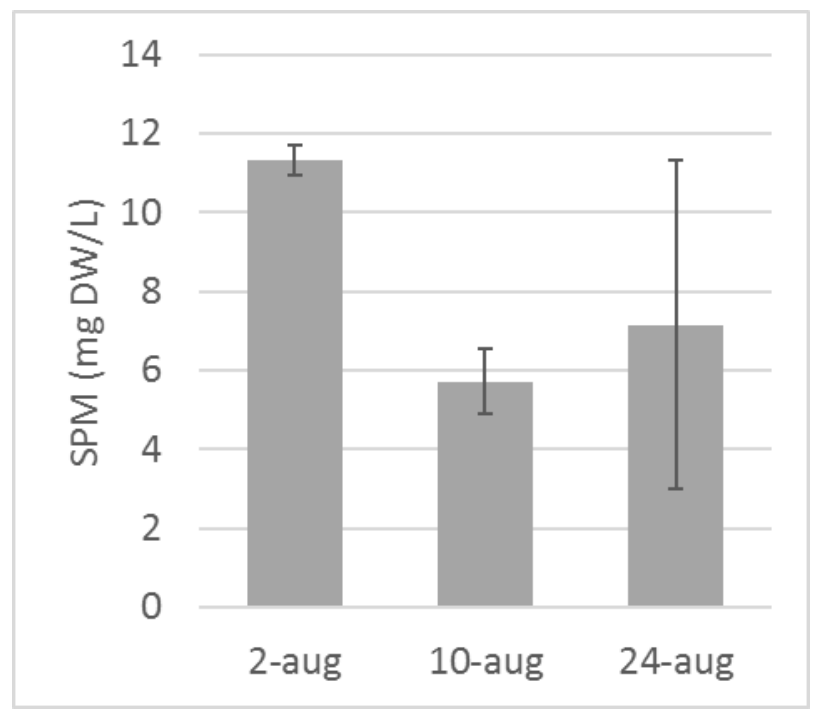

Figure 12: Grey bars indicate Suspended Particulate Matter (SPM; mg DW $L^{-1}$ ) in inflow per header tank measured during the mussel co-cultivation experiment. Error bars $(n=3)$ indicate standard deviation.

\subsection{Pre-trial: mussel Dissolved Inorganic Nutrient excretion}

The pre-trial results (Fig. 13) show that the addition of $4 \mathrm{~kg}$ of mussels is sufficient to increase the ammonium level (from 1.5 to $7 \mu \mathrm{mol} \mathrm{L}^{-1}$ ). A polynomial regression was chosen since an optimum biomass is expected, after this mussel feed will become limiting and re-filtration will occur. Both $\mathrm{NH} 4$ and PO4 concentration showed a positive correlation with mussel biomass in the tank (polynomial, $\mathrm{R}^{2}=$ 0.99 and $\mathrm{R}^{2}=0.84$ respectively) (Fig. 13).

$\mathrm{NH} 4$ level in the pre-trial (green bars) increased with $>70 \%$ when comparing header concentration with tanks containing $4 \mathrm{~kg} \mathrm{FW}$ blue mussels (Fig. 14). Mean NH4 concentration increased by $70 \%$ from 4.0

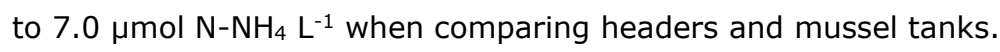




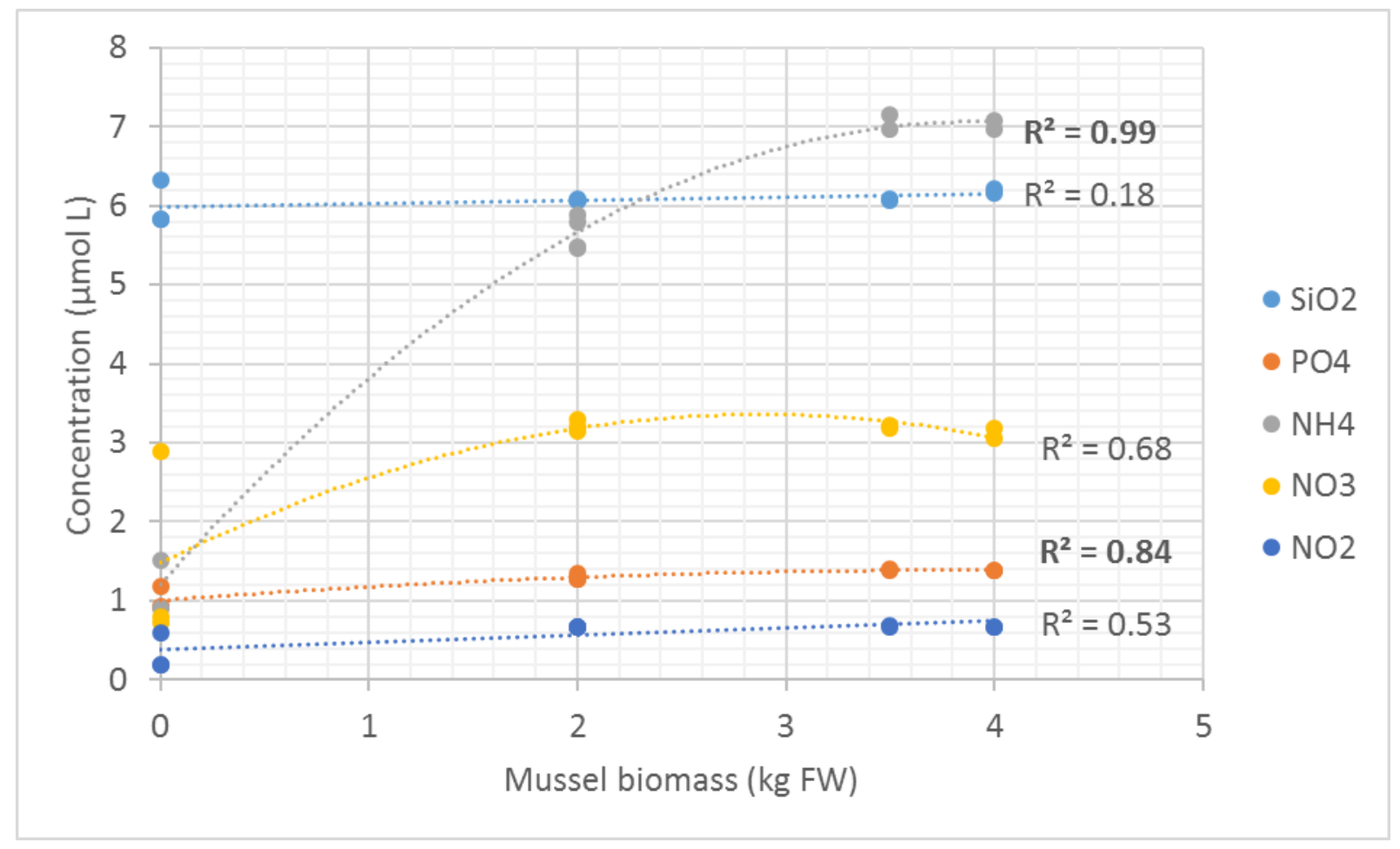

Figure 13: Concentration of dissolved silicate (blue), phosphate (orange), ammonium (grey), nitrate (yellow) and nitrite (dark blue) in the pre-trial ( $\mu \mathrm{mol} \mathrm{L}^{-1}$ ) as a function of mussel biomass added to the tank (kg FW). Dotted lines are based on polynomial regression.

\subsection{Ulva spp. productivity in monoculture and co-cultivation}

Productivity rates of Ulva spp. reared for one month in co-cultivation with blue mussels and in monoculture were comparable. No significant differences were found between treatments (ANOVA, $p>$ 0.05 ); Ulva spp. specific growth rate (SGR) was $7.7 \pm 0.86$ and $7.8 \pm 0.89 \% \mathrm{DW} \mathrm{d}^{-1}$ in mono and seaweed mussel co-cultivation respectively (Table 7 ).

The dry weight content of Ulva spp. reared in monoculture was $23.3 \%$ of fresh weight (FW) of the seaweed biomass. In co-cultivation with blue mussels, dry weight content reduced to $20.9 \% \mathrm{FW}$. Therefore, productivity expressed in DW was 90.4 and $80.0 \mathrm{~kg} \mathrm{DW} \mathrm{ha}^{-1} \mathrm{~d}^{-1}$ in monoculture and cocultivation respectively (Table 7 ).

The C: $\mathrm{N}$ ratio of the Ulva biomass (tanks containing only seaweed) measured at the start of the experiment (31/07/2018) was $17.2(S D=2.35)$. At the end of the experiment (on 28/08/2018) the $\mathrm{C}: \mathrm{N}$ ratio measured in tanks containing just seaweed and seaweed in combination with mussels was clearly lower (13.2 and 10.4 respectively, Table 7, Fig. 14). Although the C:N ratio in seaweed cultivated in combination with mussels was slightly lower than without mussels, this result was not significant (Table 7). 
Table 7: Ulva spp. productivity rate and biomass composition parameters

Ulva weight (W), specific growth rate (SGR), dry weight (DW), ash free dry weight (AFDW) (unit, mean $\pm S D, n=4)$. Letters indicate statistical significant difference between treatments, the absence of letters indicate that no statistical significant difference was observed.

$\begin{array}{lll}\text { Unit } & \text { Ulva spp. } & \text { Ulva spp. } \\ & \text { monoculture } & \text { Mussel co-cultivation }\end{array}$

\begin{tabular}{llll}
\hline $\begin{array}{l}\text { Productivity } \\
\text { Productivity }\end{array}$ & $\mathrm{kg} \mathrm{FW} \mathrm{ha}^{-1} \mathrm{~d}^{-1}$ & $388.1 \pm 92.1$ & $383.0 \pm 102.5$ \\
& $\mathrm{~kg} \mathrm{DW} \mathrm{ha}^{-1} \mathrm{~d}^{-1}$ & $90.4 \pm 21.5$ & $80.0 \pm 21.4$ \\
& & \\
N -assimilation & $\mathrm{mM} \mathrm{N} \mathrm{m}^{-2} \mathrm{~d}^{-1}$ & $38.0 \pm 3.0$ & $33.6 \pm 1.7$ \\
SGR & $\%$ DW d & $7.7 \pm 0.86^{\mathrm{a}}$ & $7.8 \pm 0.89^{\mathrm{b}}$ \\
DW & $\%$ of FW & $23.3 \pm 3.03$ & $20.9 \pm 0.66$ \\
AFDW & \% of DW & $68.6 \pm 3.12$ & $66.4 \pm 1.12$ \\
C:N ratio & - & $13.2 \pm 2.80$ & $10.4 \pm 1.29$ \\
\hline
\end{tabular}

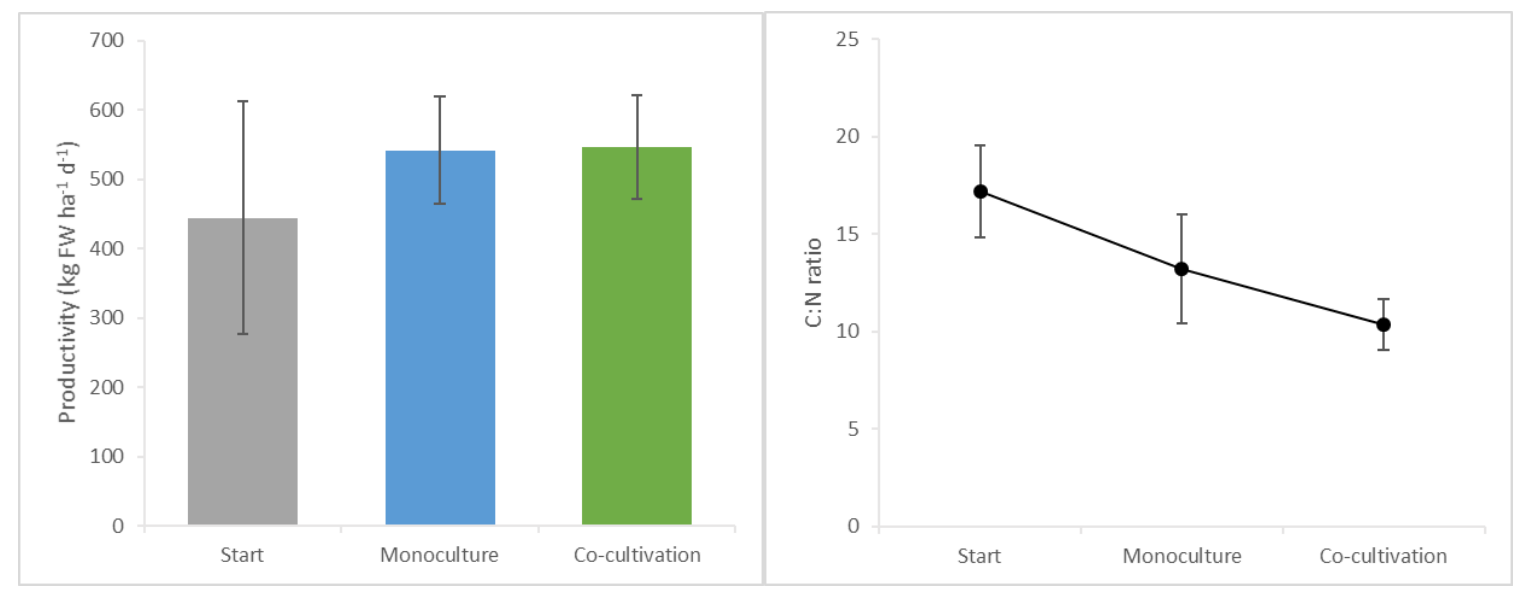

Figure 14: C:N ratio (black dots, no unit, mean $S D, n=3$ ) and productivity rate ( $k g \mathrm{FW} \mathrm{ha}^{-1} \mathrm{~d}^{-1}$, mean $S D, n=4$ ) for Ulva spp. at the beginning of the experiment (grey) and after one month of monoculture (blue bar) and one month of co-cultivation with mussels (green bar).

\subsection{Nutrient uptake Ulva-mussel experiment}

At the end of the experiment ( $t=30$ days) nitrogen uptake was measured in all tanks containing cultured Ulva spp., either in monoculture or co-cultivation with mussels (Table 5). Mean Ulva spp. ammonium removal in the seaweed tanks was highest, $56 \%$ and $66 \%$ ( 33.6 or $38.0 \mathrm{mM} \mathrm{N} \mathrm{m}^{-2} \mathrm{~d}^{-1}$ with and without mussel co-cultivation with no significant difference between the two treatments (Table 6, ANOVA, p>0.05). An increase in ammonium is expected in the mussel-seaweed tanks based on the presence of mussels. In order to correct for the increased ammonium concentration the ammonium uptake is measured. Surprisingly, no addition of ammonium was found in the tanks with mussels, and the mussel tanks even showed a reduction (uptake) of $\mathrm{NH}_{4}$ (purple bars). Ammonium removal was found to some extent in the control tanks (yellow and purple bars, Fig. 15), which is not very surprising. However, it is surprising to find ammonium uptake in the mussel only tanks. $\mathrm{PO}_{4}$ was removed in seaweed and seaweed plus mussel tanks. A high uptake of $\mathrm{SiO}_{2}$ was found in the mussel tank (Fig. 15). 
Table 5: Concentrations of Dissolved Inorganic Nutrients (DIN)

DIN concentration in pre-trial header (IN) and tanks with $4 \mathrm{~kg}$ of mussels (OUT) (equal units; mean, $n=1-2$ ) and in the tanks in inflow (IN) and outflow (OUT) ( $\mu \mathrm{mol} \mathrm{P-PO} \mathrm{L}^{-1} ; \mu \mathrm{mol} \mathrm{Si-SiO} \mathrm{L}^{-1} ; \mu \mathrm{mol} N$ $\mathrm{NH}_{4}{ }^{+} L^{-1} ; \mu \mathrm{mol} N-\mathrm{NO}_{2} L^{-1} ; \mu \mathrm{mol} N-N_{3} L^{-1} ;$ mean, $n=3$ ). Dif: indicates difference IN-OUT.

\begin{tabular}{|ll|l|lllll|}
\hline \multirow{2}{*}{ DIN } & & $\begin{array}{l}\text { Pre-trial } \\
20 / 06 / 2018\end{array}$ & \multicolumn{4}{l}{ Nutrient uptake experiment } \\
& & Mussels & $\begin{array}{l}\text { Ulva } \\
\text { mono }\end{array}$ & $\begin{array}{l}\text { Ulva } \\
\text { co-cult. }\end{array}$ & Mussels & Control & Header \\
\hline \multirow{2}{*}{$\mathrm{NH}_{4}{ }^{+}$} & IN & 4.04 & 6.07 & 6.31 & 5.64 & 5.86 & 6.85 \\
& OUT & 7.07 & 2.08 & 2.76 & 4.48 & 5.25 & - \\
\hline & Dif & $\mathbf{- 3 . 0 3}$ & $\mathbf{3 . 9 9}$ & $\mathbf{3 . 5 5}$ & $\mathbf{1 . 1 6}$ & $\mathbf{0 . 6 1}$ & - \\
\hline $\mathrm{NO}_{2}$ & IN & 0.6 & 0.75 & 0.78 & 0.76 & 0.76 & 0.75 \\
& OUT & 0.67 & 0.32 & 0.42 & 0.76 & 0.76 & - \\
\hline & Dif & -0.07 & 0.43 & 0.36 & 0 & 0 & - \\
\hline $\mathrm{NO}_{3}$ & IN & 2.89 & 3.43 & 3.56 & 3.63 & 3.53 & 3.42 \\
& OUT & 3.05 & 1.42 & 1.69 & 3.31 & 4.08 & - \\
& Dif & $\mathbf{- 0 . 1 6}$ & $\mathbf{2 . 0 1}$ & $\mathbf{1 . 8 7}$ & $\mathbf{0 . 3 2}$ & $\mathbf{- 0 . 5 5}$ & - \\
\hline $\mathrm{PO}_{4}$ & IN & 1.18 & 1.89 & 1.91 & 1.9 & 1.91 & 1.91 \\
& OUT & 1.38 & 1.57 & 1.63 & 1.87 & 1.96 & - \\
\hline & Dif & $\mathbf{- 0 . 2 0}$ & $\mathbf{0 . 3 2}$ & $\mathbf{0 . 2 8}$ & $\mathbf{0 . 0 3}$ & $\mathbf{- 0 . 0 5}$ & - \\
\hline $\mathrm{SiO}_{2}$ & IN & 6.32 & 4.17 & 4.19 & 4.28 & 4.26 & 4.36 \\
& OUT & 6.16 & 3.58 & 3.72 & 2.96 & 3.78 & - \\
\hline & Dif & $\mathbf{0 . 1 6}$ & $\mathbf{0 . 5 9}$ & $\mathbf{0 . 4 7}$ & $\mathbf{1 . 3 2}$ & $\mathbf{0 . 4 8}$ & - \\
\hline & & & & & & & \\
\hline
\end{tabular}

Table 6: DIN uptake

Dissolved inorganic nutrient (DIN) uptake $(\%$, mean $\pm S D, n=3)$. Significant differences are indicated with letters (for example $a$ is sign. different from $b$ ).

\begin{tabular}{lccccc}
\hline DIN & $\begin{array}{c}\text { Ulva } \\
\text { monoculture }\end{array}$ & $\begin{array}{c}\text { Ulva } \\
\text { co-cultivation }\end{array}$ & Mussels & Control & ANOVA p \\
\hline $\mathrm{NH}_{4}$ & $65.8 \pm 5.3^{\mathrm{a}}$ & $56.3 \pm 4.9^{\mathrm{a}}$ & $20.5 \pm 4.3^{\mathrm{b}}$ & $9.9 \pm 13.8^{\mathrm{b}}$ & $<0.001$ \\
$\mathrm{NO}_{2}$ & $56.6 \pm 6.9^{\mathrm{a}}$ & $46.3 \pm 15.6^{\mathrm{a}}$ & $5.7 \pm 3.4^{\mathrm{b}}$ & $-0.9 \pm 1.5^{\mathrm{b}}$ & $<0.001$ \\
$\mathrm{NO}_{3}$ & $58.8 \pm 5.5^{\mathrm{a}}$ & $52.1 \pm 14.0^{\mathrm{a}}$ & $8.8 \pm 3.5^{\mathrm{b}}$ & $-15.7 \pm 3.5^{\mathrm{c}}$ & $<0.001$ \\
$\mathrm{PO}_{4}$ & $17.1 \pm 2.5^{\mathrm{a}}$ & $14.7 \pm 7.3^{\mathrm{a}}$ & $1.4 \pm 1.2^{\mathrm{b}}$ & $-3.0 \pm 4.3^{\mathrm{b}}$ & $<0.01$ \\
$\mathrm{SiO}_{2}$ & $14.1 \pm 1.8^{\mathrm{b}}$ & $11.3 \pm 2.3^{\mathrm{b}}$ & $31.0 \pm 6.2^{\mathrm{a}}$ & $11.3 \pm 2.9^{\mathrm{b}}$ & $<0.001$ \\
\hline
\end{tabular}




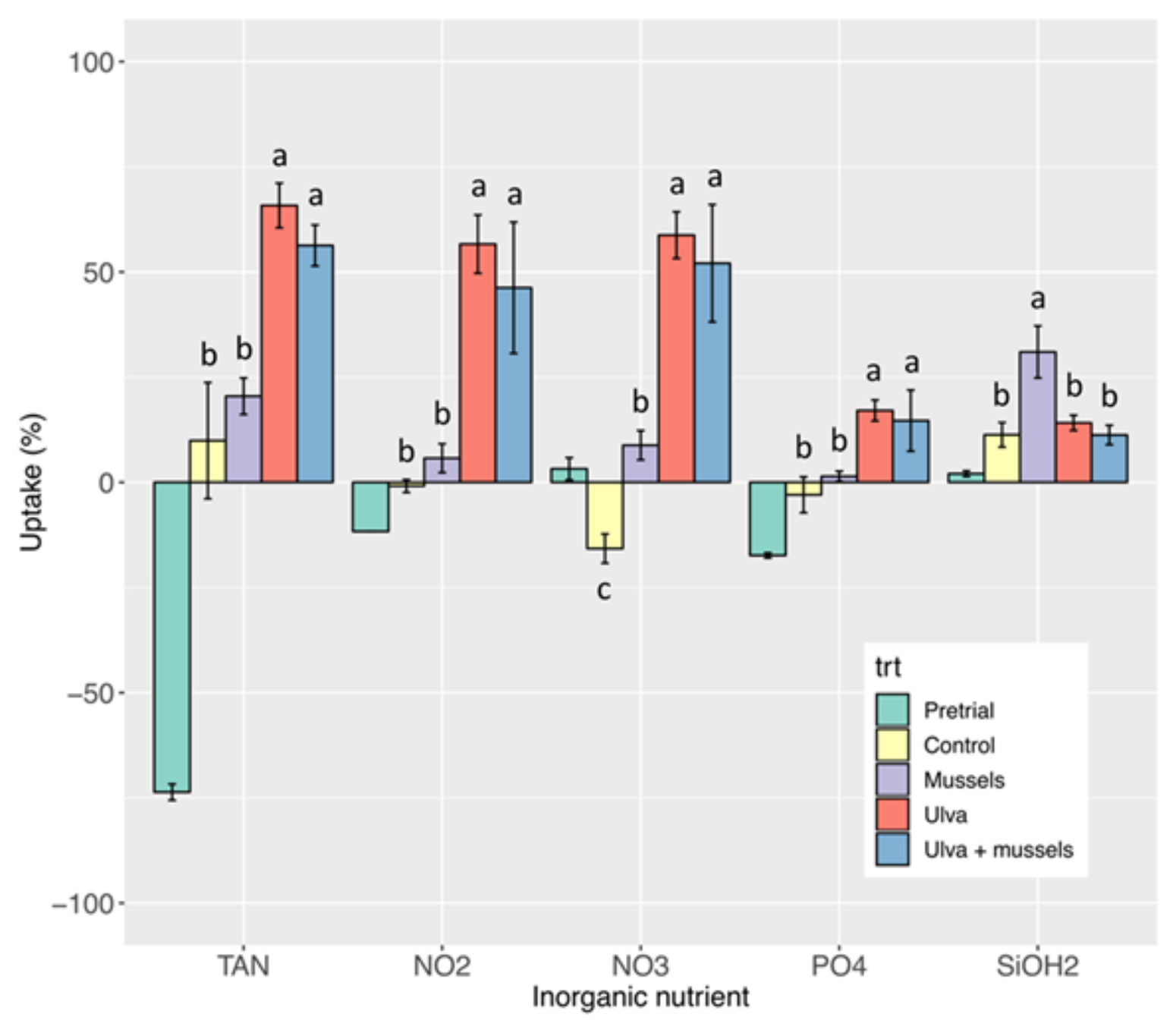

Figure 15: DIN uptake (\% of inflow concentration removed, mean $\pm S D, N=3$ ) for each experimental treatment; Control (no mussels + no Ulva) (yellow), Mussels (purple), Ulva (red), Ulva + mussels (blue). Pre-trial (green) is percentage nutrient addition in the tanks containing mussels when compared to header tanks $(N=2)$. Significant differences $(p<0.01)$ between experimental treatments (excluding pre-trial) are indicated with letters (for example: $a$ is sign. different from $b$ ). 


\section{Discussion and recommendations}

\subsection{Main outcomes}

The pre-trial experiment showed that the addition of $4 \mathrm{~kg}$ mussels almost doubled the ammonium concentration measured in the tanks at a flow rate 0 f $32.5 \mathrm{~mL} \mathrm{sec}^{-1}$, and could result in higher growth of Ulva under nitrogen limited conditions and/or higher availability of the low energy requesting $\mathrm{N}$ form (ammonium). The productivity rates of Ulva were, however, comparable for both treatments (with and without mussels). The $\mathrm{C}: \mathrm{N}$ ratio in Ulva biomass did not significantly differ between treatments but was lower at the end of the experiment, indicating $\mathrm{N}$ was limited at the start of the experiment and limitation decreased during the experiment (concordantly with increasing $\mathrm{N}$ concentration over summer [Fig. 9]). The lack of significant difference between treatments might indicate that Ulva is not affected by higher nutrient concentration nor by availability of ammonium. However the nutrient uptake experiment showed that ammonium concentrations were not elevated by the presence of mussels. This is not in accordance to our expectation, but is in line with the absence of enhanced growth.

\subsection{Benefits of Ulva spp. and mussel co-cultivation}

Pre-trial results showed $>70 \%$ increase of ammonium- $\mathrm{N}$ concentration in the tanks, validating our assumption that the experimental set-up enabled the mussels to be used as additional nitrogen source for seaweed growth. Ammonium concentrations in the flow-through tanks of the experimental set-up increased with $3.12 \mu \mathrm{mol}-\mathrm{N} \mathrm{L}^{-1}$ when $4 \mathrm{~kg}$ FW mussels were added. This is equal to an ammonium-N excretion rate of $1 \mu \mathrm{mol}-\mathrm{N} \mathrm{g}^{-1} \mathrm{DW} \mathrm{h}^{-1}$, as is also found in literature (Jansen et al., 2012, Smaal \& Vonck, 1997), assuming a mussel biomass conversion ratio of 6.6 SFDW/FW (Ricciardi et al., 1997). However, nutrient uptake (difference between in- and outflow $\mathrm{NH}_{4}$ levels in the tanks) determined after the 30 days of the Ulva spp. and mussel co-cultivation experiment did no longer support the assumption of ammonium release by the mussels. Moreover, a de- rather than increase in $\mathrm{NH}_{4}$ concentrations was detected when comparing in- and outflow in the mussel only tanks. This does not match increased ammonium-N concentrations as reported in proximity of mussel longlines by field observations (Jansen et al., 2012, Smaal, 2002).

The lack of nitrogen enhancement coincides with the lack in observed productivity increase for Ulva cultured in combination with mussels. No difference was found in productivity rates of Ulva cultivated with and without the addition of mussels, although 4 weeks are deemed sufficient to note an increase

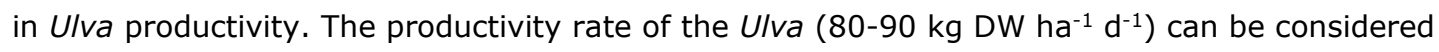
normal as it is in the same range of $U$. lactuca growth in temperate regions as reported in literature (Bruhn et al., 2011, Debusk et al., 1986, Robertson-Andersson et al., 2008a)see also table 1) despite exceptionally warm and dry conditions during July-September 2018. Furthermore, C:N ratios were similar for Ulva cultivated in mono or co-culture with mussels. Though not statistically different, lowest ratio was found in combination with mussels, which is in line with an expected higher $\mathrm{N}$ supply and potentially indicative for the higher net ammonium uptake by Ulva cultivated in combination with mussels.

The question is whether the lack in growth difference and similarity in $\mathrm{C}: \mathrm{N}$ ratios between monoculture and co-cultivation treatments is because $\mathrm{N}$ was not limited and ammonium is not preferred by Ulva, or if $\mathrm{N}$ concentrations were not enhanced by addition of mussels. The nutrient uptake experiments were only performed once (point measurement) and do not provide evidence whether $\mathrm{N}$ addition has been low throughout the experiment, but the lack of enhanced $\mathrm{N}$ concentration in mussel tanks highlight an unexpected result. 
Several factors were considered that could have contributed to the unexpected result. Although no evidence to support these theories was found and these factors are merely hypothetical they will be addressed here briefly. 1) We considered the mesocosm set-up which may facilitate competition for nutrients by fouling micro-organisms such as autotrophic periphyton (microalgae, bacteria, fungi), heterotrophic bacteria or phototrophic fouling organisms that have accumulated despite regular cleaning. In this scenario, ammonium is excreted by the mussels but strong competition for nitrogen impedes assimilation by macroalgae (Ulva spp.). Fouling was heaviest in the control tanks where no competition for nutrients from macro-algae existed. Considering that ammonium uptake in fouled control tanks was low it is unlikely that the micro-organisms in the Ulva plus mussel cultivation tanks account for a large proportion of the ammonium uptake..

2) Aerobic nitrification by so-called nitrifying bacteria converts ammonium into nitrate in an aerobic environment. This process is abundant in marine systems (Wuchter et al., 2006). In this transformation process ammonium is transformed into nitrite $\left(\mathrm{NO}_{2}^{-}\right.$, toxic and nitrite $\left(\mathrm{NO}_{2}{ }^{-}\right)$is converted into nitrate $\left(\mathrm{NO}_{3}{ }^{-}\right)$. However this should result in an increase in $\mathrm{NO}_{3}{ }^{-}$which was not detected. Again, although these processes may have occurred at a small scale they are unlikely to account for the breakdown of the ammonium excreted by mussels.

A potential explanation of low ammonium-N excretion could be due to the mussels. 3) Mussels could have been affected by limited food availability. Mussels have shown to adapt to a range of 10 $90 \mathrm{mg} \mathrm{L}^{-1}$ (SPM) (Bayne, 1998, Hawkins et al., 1998). SPM levels ranged between $5.3-11.7 \mathrm{mg} \mathrm{L}^{-1}$ and decreased during August 2018 (Fig. 12, note that SPM levels as measured in this study are potentially underestimated due to rinsing with fresh water instead of $\mathrm{HCO}_{2} \mathrm{NH}_{4}$ ). However, large variation in SPM levels measured in the inflow headers at $24^{\text {th }}$ of August could be an indication that header conditions (turbulence, sedimentation processes) might have been a factor contributing to changes in SPM throughout the experiment, as was accounted for by the randomized set-up of the experimental design. On the other hand, M. edulis is adapted to low phytoplankton concentrations and filtrates continuously when the food concentration reaches above a trigger value of about 0.5 to 0.9

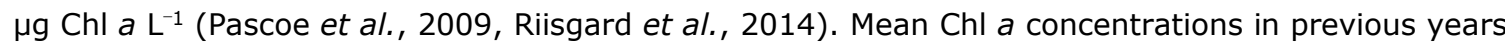

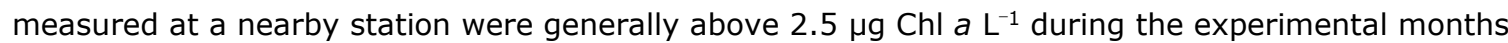
(July -September) (Fig. 10) making food shortage a less likely candidate.

4) Although the mussels did not show significant growth over the 5 week period of the experiment the relatively high survival rates ( $>80 \%, t=30$ days) indicate all environmental parameters in the culture tanks (temperature, $\mathrm{pH}$, dissolved oxygen, SPM) were within the acceptable range for healthy mussel metabolism. During tank observations, no signs of stress were observed; the majority of shells were open when submerged and closed when mussels were taken out of the water. Mussels that remained open above water were removed from the tanks directly after observation to avoid contamination from degrading mussel biomass. Nonetheless heat stress in mussels is well documented and although temperature stress may potentially increase metabolism and ammonium excretion to a certain extent, lethal temperatures of 30-31 ${ }^{\circ} \mathrm{C}$ have been indicated for M. edulis, while respiration rates of North Sea Mytilus spp. population decline above $24{ }^{\circ} \mathrm{C}$ (Jansen et al., 2007, Wallis, 1975). It is therefore possible that the extreme weather conditions (temperatures over $35^{\circ} \mathrm{C}$ ) have had an effect on the mussels metabolism and thereby the excretion of ammonium. The remaining question is then whether the mussel metabolism itself may have been impaired throughout the experimental period, even if impaired they would have still excreted ammonium to some extent, considering the mussels appeared in good health with high survival rates this explanation is unlikely.

It remains unknown why no enhanced ammonium concentrations were observed during the end of the experiment, and whether or not this has occurred throughout the experimental period, subsequently leading to little variation in growth and $\mathrm{C}: \mathrm{N}$ ratios between mono- and co-culture treatments.

\subsection{Relevance for commercial cultivation}

Although this study does not show a clear benefit from co-cultivation of Ulva with mussels to increase productivity, a potential benefit can also not be ruled out as a result of uncertainties in the outcomes and absence of ammonia excretion during the co-cultivation experiment in comparison to the pre-trial. 
Lower C:N ratios (though not significant) in co-cultivated Ulva may hint towards higher uptake of nitrogen in treatments with mussels.

\subsection{Recommendations}

More frequent DIN measurements may have given a clearer pattern and potentially resolve uncertainties following the nutrient uptake experiments. Budget calculations using simple models to understand the system can provide insight in whether the mesocosms used in this study could have acted as a complex ecotype which is not fully understood. Unforeseen extreme conditions such as the high temperatures may have had consequences for the mussel metabolism. Repeat measurements throughout the summer season could resolve this. A more direct or theoretical approach can be chosen by which the mussels itself are not included in the growth experiment but instead ammonium concentrations are increased directly. Greater effects may be obtained by using young sporophytes that appear to be more susceptible to the uptake of added nutrients (Mortensen, 2017). 


\section{Conclusion}

Co-cultivation with mussels did not increase Ulva production. Despite the addition of mussels was deemed sufficient to increase initial ammonium concentrations in a pre-trial experiment. This result was supported by the $\mathrm{C}: \mathrm{N}$ ratios of the Ulva biomass and the results from the nutrient uptake experiment. It remains unknown why no enhanced ammonium concentrations were observed during the end of the experiment, and whether or not this has occurred throughout the experimental period, subsequently leading to little variation in growth and $\mathrm{C}: \mathrm{N}$ ratios between mono- and co-culture treatments. 


\section{Quality Assurance}

Wageningen Marine Research utilises an ISO 9001:2015 certified quality management system. This certificate is valid until 15 December 2021. The organisation has been certified since 27 February 2001. The certification was issued by DNV GL.

Furthermore, the chemical laboratory at IJmuiden has NEN-EN-ISO/IEC 17025:2005 accreditation for test laboratories with number L097. This accreditation is valid until $1^{\text {th }}$ of April 2021 and was first issued on 27 March 1997. Accreditation was granted by the Council for Accreditation. The chemical laboratory at IJmuiden has thus demonstrated its ability to provide valid results according a technically competent manner and to work according to the ISO 17025 standard. The scope (L097) of de accredited analytical methods can be found at the website of the Council for Accreditation (www.rva.nl).

On the basis of this accreditation, the quality characteristic $Q$ is awarded to the results of those components which are incorporated in the scope, provided they comply with all quality requirements. The quality characteristic $\mathrm{Q}$ is stated in the tables with the results. If, the quality characteristic $\mathrm{Q}$ is not mentioned, the reason why is explained.

The quality of the test methods is ensured in various ways. The accuracy of the analysis is regularly assessed by participation in inter-laboratory performance studies including those organized by QUASIMEME. If no inter-laboratory study is available, a second-level control is performed. In addition, a first-level control is performed for each series of measurements.

In addition to the line controls the following general quality controls are carried out:

- Blank research.

- Recovery.

- Internal standard

- Injection standard.

- Sensitivity.

The above controls are described in Wageningen Marine Research working instruction ISW 2.10.2.105. If desired, information regarding the performance characteristics of the analytical methods is available at the chemical laboratory at IJmuiden.

If the quality cannot be guaranteed, appropriate measures are taken. 


\section{References}

Ajjabi, L. C., Abaab, M. \& Segni, R. 2018. The red macroalga Gracilaria verrucosa in co-culture with the Mediterranean mussels Mytilus galloprovincialis: productivity and nutrient removal performance. Aquaculture International 26:253-66.

Bakker, C., Herman, P. \& Vink, M. 1994. A new trend in the development of the phytoplankton in the Oosterschelde (SW Netherlands) during and after the construction of a storm-surge barrier. The Oosterschelde Estuary (The Netherlands): a Case-Study of a Changing Ecosystem. Springer, pp. 79100.

Bayne, B. L. 1998. The physiology of suspension feeding by bivalve molluscs: an introduction to the Plymouth "TROPHEE" workshop. Journal of Experimental Marine Biology and Ecology 219:1-19.

Bouwman, A. F., Pawłowski, M., Liu, C., Beusen, A. H., Shumway, S. E., Glibert, P. \& Overbeek, C. 2011 a. Global hindcasts and future projections of coastal nitrogen and phosphorus loads due to shellfish and seaweed aquaculture. Reviews in Fisheries Science 19:331-57.

Bouwman, A. F., Pawlowski, M., Liu, C., Beusen, A. H. W., Shumway, S. E., Glibert, P. M. \& Overbeek, C. C. 2011b. Global Hindcasts and Future Projections of Coastal Nitrogen and Phosphorus Loads Due to Shellfish and Seaweed Aquaculture. Rev Fish Sci 19:331-57.

Bruhn, A., Dahl, J., Nielsen, H. B., Nikolaisen, L., Rasmussen, M. B., Markager, S., Olesen, B., Arias, C. \& Jensen, P. D. 2011. Bioenergy potential of Ulva lactuca: Biomass yield, methane production and combustion. Bioresource Technology 102:2595-604.

Buschmann, A. H., Cabello, F., Young, K., Carvajal, J., Varela, D. A. \& Henriquez, L. 2009. Salmon aquaculture and coastal ecosystem health in Chile: Analysis of regulations, environmental impacts and bioremediation systems. Ocean \& Coastal Management 52:243-49.

Cohen, I. \& Neori, A. 1991a. Ulva-Lactuca Biofilters for Marine Fishpond Effluents .1. Ammonia Uptake Kinetics and Nitrogen-Content. Botanica Marina 34:475-82.

Cohen, I. \& Neori, A. 1991b. Ulva lactuca biofilters for marine fishpond effluents. I. Ammonia uptake kinetics and nitrogen content. Botanica Marina 34:475-82.

Cohen, R. A. \& Fong, P. 2004. Nitrogen uptake and assimilation in Enteromorpha intestinalis (L.) Link (Chlorophyta): using $\mathrm{N}-15$ to determine preference during simultaneous pulses of nitrate and ammonium. J Exp Mar Biol Ecol 309:67-77.

D'Elia, C. F. \& DeBoer, J. A. 1978. Nutritional studies of two red algae. II. kinetics of ammonium and nitrate uptake 1, 2. Journal of Phycology 14:266-72.

de Vries, I. 2014. Waterkwaliteiten Deltawateren: datarapport Oosterschelde.

Debusk, T. A., Blakeslee, M. \& Ryther, J. H. 1986. Studies on the Outdoor Cultivation of Ulva-Lactuca L. Botanica Marina 29:381-86.

Duke, C., Litaker, W. \& Ramus, J. 1989. Effect of temperature on nitrogen-limited growth rate and chemical composition of Ulva curvata (Ulvales: Chlorophyta). Marine Biology 100:143-50.

Duke, C. S., Lapointe, B. E. \& Ramus, J. 1986. Effects of Light on Growth, Rubpcase Activity and ChemicalComposition of Ulva Species (Chlorophyta). Journal of Phycology 22:362-70.

Fujita, R. M. 1985. The role of nitrogen status in regulating transient ammonium uptake and nitrogen storage by macroalgae. Journal of Experimental Marine Biology and Ecology 92:283-301.

Groenendijk, F. C., Bikker, P., Blaauw, R., Brandenburg, W. A., Burg, S. W. K. v. d., Harmsen, P. F. H., Jak, R. G., Kamermans, P., Krimpen, M. M. v., Prins, H., Stuiver, M., Werf, A. K. v. d., Scholl, M. M. \& Wald, J. 2016. North-Sea-Weed-Chain: sustainable seaweed from the North Sea; an exploration of the value chain. IMARES.

Hawkins, A. J. S., Bayne, B. L., Bougrier, S., Heral, M., Iglesias, J. I. P., Navarro, E., Smith, R. F. M. \& Urrutia, M. B. 1998. Some general relationships in comparing the feeding physiology of suspensionfeeding bivalve molluscs. Journal of Experimental Marine Biology and Ecology 219:87-103.

Hurd, C. L., Harrison, P. J., Bischof, K., \& Lobban, C. S. 2014. Seaweed ecology and physiology. Cambridge University Press., Cambridge, UK,

Jansen, H. M., Strand, O., Verdegem, M. \& Smaal, A. 2012. Accumulation, release and turnover of nutrients (C-N-P-Si) by the blue mussel Mytilus edulis under oligotrophic conditions. J Exp Mar Biol Ecol 416:185-95.

Jansen, J. M., Pronker, A. E., Kube, S., Sokolowski, A., Sola, J. C., Marquiegui, M. A., Schiedek, D., Bonga, S. W., Wolowicz, M. \& Hummel, H. 2007. Geographic and seasonal patterns and limits on the adaptive response to temperature of European Mytilus spp. and Macoma balthica populations. Oecologia 154:23-34. 
Lamare, M. D. \& Wing, S. R. 2001. Calorific content of New Zealand marine macrophytes. New Zeal J Mar Fresh 35:335-41.

Lapointe, B. E. \& Duke, C. S. 1984. BIOCHEMICAL STRATEGIES FOR GROWTH OF GRACILARIA-TIKVAHIAE (RHODOPHYTA) IN RELATION TO LIGHT-INTENSITY AND NITROGEN AVAILABILITY. Journal of Phycology 20:488-95.

Lapointe, B. E., Williams, L. D., Goldman, J. C. \& Ryther, J. H. 1976. The mass outdoor culture of macroscopic marine algae. Aquaculture 8:9-21.

Lavery, P. S., Lukatelich, R. \& McComb, A. 1991a. Changes in the biomass and species composition of macroalgae in a eutrophic estuary. Estuarine, Coastal and Shelf Science 33:1-22.

Lavery, P. S., Lukatelich, R. J. \& Mccomb, A. J. 1991b. Changes in the Biomass and Species Composition of Macroalgae in a Eutrophic Estuary. Estuar Coast Shelf $S$ 33:1-22.

Mao, Y., Yang, H., Zhou, Y., Ye, N. \& Fang, J. 2009a. Potential of the seaweed Gracilaria lemaneiformis for integrated multi-trophic aquaculture with scallop Chlamys farreri in North China. Journal of applied phycology 21:649.

Mao, Y. Z., Yang, H. S., Zhou, Y., Ye, N. H. \& Fang, J. G. 2009b. Potential of the seaweed Gracilaria lemaneiformis for integrated multi-trophic aquaculture with scallop Chlamys farreri in North China. J. Appl. Phycol. 21:649-56.

Michler-Cieluch, T. \& Kodeih, S. 2008. Mussel and seaweed cultivation in offshore wind farms: An opinion survey. Coast Manage 36:392-411.

Mortensen, L. M. 2017. Remediation of nutrient-rich, brackish fjord water through production of protein-rich kelp S-latissima and L-digitata. J. Appl. Phycol. 29:3089-96.

Neori, A., Cohen, I. \& Gordin, H. 1991a. Ulva-Lactuca Biofilters for Marine Fishpond Effluents .2. GrowthRate, Yield and C-N Ratio. Botanica Marina 34:483-89.

Neori, A., Cohen, I. \& Gordin, H. 1991b. Ulva lactuca biofilters for marine fishpond effluents. II. Growth rate, yield and C: N ratio. Botanica Marina 34:483-90.

Pascoe, P. L., Parry, H. E. \& Hawkins, A. J. S. 2009. Observations on the measurement and interpretation of clearance rate variations in suspension-feeding bivalve shellfish. Aquat Biol 6:181-90.

Pinchetti, J. L. G., Fernandez, E. D., Diez, P. M. \& Reina, G. G. 1998. Nitrogen availability influences the biochemical composition and photosynthesis of tank-cultivated Ulva rigida (Chlorophyta). J. Appl. Phycol. 10:383-89.

Ricciardi, A., Whoriskey, F. G. \& Rasmussen, J. B. 1997. The role of the zebra mussel (Dreissena polymorpha) in structuring macroinvertebrate communities on hard substrata. Can J Fish Aquat Sci 54:2596-608.

Riisgard, H. U., Larsen, P. S., Turja, R. \& Lundgreen, K. 2014. Dwarfism of blue mussels in the low saline Baltic Sea - growth to the lower salinity limit. Marine Ecology Progress Series 517:181-92.

Robertson-Andersson, D., Potgieter, M., Hansen, J., Bolton, J., Troell, M., Anderson, R., Halling, C. \& Probyn, T. 2008a. Integrated seaweed cultivation on an abalone farm in South Africa. J. Appl. Phycol. 20:579-95.

Robertson-Andersson, D. V., Potgieter, M., Hansen, J., Bolton, J. J., Troell, M., Anderson, R. J., Halling, C. \& Probyn, T. 2008b. Integrated seaweed cultivation on an abalone farm in South Africa. Journal of Applied Phycology 20:579-95.

Rose, J. M., Bricker, S. B., Deonarine, S., Ferreira, J. G., Getchis, T., Grant, J., Kim, J. K., Krumholz, J. S., Kraemer, G. P., Stephenson, K., Wikfors, G. H. \& Yarish, C. 2015. Nutrient Bioextraction. In: Meyers, R. A. [Ed.] Encyclopedia of Sustainability Science and Technology. Springer Science and Business Media, New York.

Rosenberg, C. \& Ramus, J. 1982. Ecological growth strategies in the seaweeds Gracilaria foliifera (Rhodophyceae) and Ulva sp.(Chlorophyceae): soluble nitrogen and reserve carbohydrates. Marine Biology 66:251-59.

Rossner, Y., Krost, P. \& Schulz, C. 2014. Increasing seaweed crop yields through organic fertilisation at the nursery stage. J. Appl. Phycol. 26:753-62.

Sanderson, J. C., Cromey, C. J., Dring, M. J. \& Kelly, M. S. 2008. Distribution of nutrients for seaweed cultivation around salmon cages at farm sites in north-west Scotland. Aquaculture 278:60-68.

Smaal, A. C. 2002. European mussel cultivation along the Atlantic coast: production status, problems and perspectives. Hydrobiologia 484:89-98.

Smaal, A. C. \& Vonck, A. P. M. A. 1997. Seasonal variation in C, N and P budgets and tissue composition of the mussel Mytilus edulis. Mar. Ecol. Prog. Ser. 153:167-79.

Solidoro, C., Pecenik, G., Pastres, R., Franco, D. \& Dejak, C. 1997. Modelling macroalgae (Ulva rigida) in the Venice lagoon: Model structure identification and first parameters estimation. Ecological Modelling 94:191-206.

van den Burg, S. W. K., Kamermans, P., Blanch, M., Pletsas, D., Poelman, M., Soma, K. \& Dalton, G. 2017. Business case for mussel aquaculture in offshore wind farms in the North Sea. Mar Policy 85:1-7. 
Wallis, R. L. 1975. THERMAL TOLERANCE OF MYTILUS-EDULIS OF EASTERN AUSTRALIA. Marine Biology 30:183-91.

Wijsman, J. W. M., Troost, K., Fang, J. \& Roncarati, A. 2019. Global production of marine bivalves. Trends and challenges. In: Smaal, A. C., Ferreira, J. G., Grant, J., Petersen, J. K. \& Strand, Ø. [Eds.] Goods and services of marine bivalves. Springer, pp. 7-26.

Wuchter, C., Abbas, B., Coolen, M. J., Herfort, L., van Bleijswijk, J., Timmers, P., Strous, M., Teira, E., Herndl, G. J., Middelburg, J. J., Schouten, S. \& Sinninghe Damste, J. S. 2006. Archaeal nitrification in the ocean. Proc Natl Acad Sci U S A 103:12317-22. 


\section{Justification}

Report C011/19

Project Number: 431810017

The scientific quality of this report has been peer reviewed by a colleague scientist and a member of the Management Team of Wageningen Marine Research

Approved: $\quad$ Dr. ir. J. Wijsman

senior scientist

Signature:

Date:

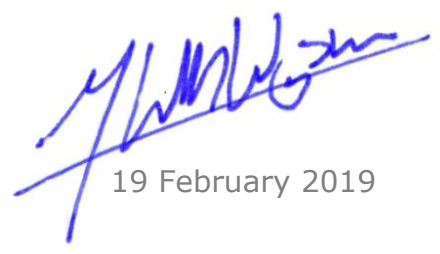

Approved:

Dr. J. Asjes

Manager Integration

Signature:

Date:

19 February 2019 
Wageningen Marine Research

T +31(0)317480900

E: marine-research@wur.nl

www.wur.eu/marine-research

Visitors' address

- Ankerpark 271781 AG Den Helder

- Korringaweg 7, 4401 NT Yerseke

- Haringkade 1, 1976 CP IJmuiden
Wageningen Marine Research is the Netherlands research institute established to provide the scientific support that is essential for developing policies and innovation in respect of the marine environment, fishery activities, aquaculture and the maritime sector.

\section{Wageningen University \& Research:}

is specialised in the domain of healthy food and living environment.

\section{The Wageningen Marine Research vision}

'To explore the potential of marine nature to improve the quality of life'

\section{The Wageningen Marine Research mission}

- To conduct research with the aim of acquiring knowledge and offering advice on the sustainable management and use of marine and coastal areas.

- Wageningen Marine Research is an independent, leading scientific research institute

Wageningen Marine Research is part of the international knowledge organisation Wageningen UR (University \& Research centre). Within Wageningen UR, nine specialised research institutes of the Stichting Wageningen Research Foundation have joined forces with Wageningen University to help answer the most important questions in the domain of healthy food and living environment. 